\title{
Social Spaces and Acting Society
}

\author{
Csaba Makó and Agnes Simonyi
}

\begin{abstract}
"A widely spread belief in modern social science is that continuity needs no explanation. Change is considered as a problem to explain. This approach makes the researcher blind to perceive the social dimension of decisive importance"

(B. More, 1969, C. Trigilia, 1986)
\end{abstract}

\section{Emerging Interpretation of the Changing World of Labour}

More than four decades of peaceful development in the highly industrialized countries of the world were devoted to observe economic and social processes as well as to forecast their fulfilment or revision. Sociologists tried to identify the social expectations as well as the possibilities and the conditions of adjustment to change in the background of such new phenomena as welfare and migration, powerful trade unions, alienated workers and massive strikes, declining and rising industries, emerging and vanishing trades, revolutionary technical inventions, changing workorganizations and human relations. In this paper we try to sum up the latest experiences of sociology collected within the labour-economy and society triangle. We analyze how and why sociology is recriminating its questions and, instead of giving answers, redesigning not its answers but its relation to an acting society.

Together with our French, British, Italian, Swedish and German colleagues, we have been surprised by the fact that in recent years, the opportunities of forming autonomous work groups and the right to participate were not seized by masses of workers. We had to acknowledge that new technologies opened room for both the individualization of labour and the emergence of the network systems of hundreds of small enterprises. Our sociological imagination was moved by militant and leftists when trade unions in some countries began to loose their members, while in other countries masses were supporting there trying to revitalize organizations hardly showing any "sign of trade union life". (Maurice, 1988; Kasvio, 1985; Reyneri, 1987; Kalleberg, 1988; Dubois, 1985; Van Hoof, 12984; Lutz, 1981).

At international conferences of the 1980s (Lake Balaton in 1984; Amsterdam in 1985; Bologna in 1986; Paris in 1988; Kecskemet in 1988, etc) it has been pointed out in various ways that the development of social reality follows schemes different from those predicted. While the socially 
conditioned nature of productive innovations has been increasingly emphasized, social sciences are hesitating to identify the nature of developments. Analyses of work organizations, of informal relationships, of the hidden economy and of the world of undertakings have called attention not only to the persistence of professional and cultural traditions, family ties and bonds of local "microsocieties", but also to the indispensability of such premodern patterns for the functioning of modern structures.

So we must distinguish between modernization and ruining down the old. Our conception of development must be revised. Our evolutionist sense of security must be abandoned and we have started to discover within different social and organizational forms, those types of mutations that in some elements, point towards new social alternatives. It is a difficult task because instead of recognizing hierarchical and horizontal relations forces and counter-forces within a dominant model, the researchers must have a comprehensive view of the segmented systems of social relations which are the fabric of various and heterogeneous networks. Moreover to deal at the same time with the complexity of the present and the emerging alternatives needs scientific imagination.

Our thinking has been encouraged in that direction by the fact that the need to break with the various types of determinism was made evident at the end of the 1980 s by industrial sociologists of different countries. Neither organizational and technological determinism nor the determinism of the given social and political relations would enable us to understand the vitality or inadaptability of different nations, regions, enterprises or social groups. At the same time the more intense and complex studies of different social phenomena and, last but not least, the debates about the various "types of determinism" have made researchers aware that in both time and space the individuals are acting in several social formations.

Human relations established simultaneously in several economic forms and social fields serve to sustain already existing institutions and structures while forging new ones as well. In one's life and working experiences, the different social and economic formations are continuously linked during the processes of decisions and mobility, thus creating bonds between social institutions, structures and spaces. The spread of network analysis reflects that approach already in sociology (Szociologiai Figyelö, no. 3 of 1988). Some of the related works (Granovetter, 1988) have revealed dualities like social stability and change or cultural determinism of behaviours and the freedom of autonomous actions in the social networks. The different types of relations, with varying intensity, among the individuals and their groups belonging to overlapping networks, are the guarantees of social stability on the one hand and allow some scope for personal freedom and manipulation of the structure on the other (Angelusz/Tardos, 1988: 12). 


\section{Debates Among Industrial Sociologists in the 1980s: New Forms of Determinism}

By the end of the 1960 s, analyses of the social impact of technological progress appeared to have definitively disproved both the optimistic and pessimistic versions of the concepts of technical determinism. The highstandard engineering work has not become general through the scientifictechnical revolution nor did automation reduce man to the status of robot. Research disclosed combined effects of management systems, organization of work, and social and political environments in the most diverse cases of technical development (Kasvio, 1986).

However, by the 1980 s, the long-standing dispute flared up again, this time on the social impact of the industrial application of microelectronics, when through the "third industrial revolution" radical changes in employment and skill level have been expected. The following quotation from a Japanese study reflects the view of many other research workers, including Hungarians: "Industrial robots, machine tools of digital guidance, computerized planning and manufacture, flexible production systems and the automation of clerical work serve to radically change the content of work, the work organisation and the structure and strategy of management" (Okubayashi, 1986: 7). The social and human perspectives opened by the use of new technologies were outlined in rather simplified form also by the international conferences on automation which took place in Hungary in the mid-1980s:

"those qualified and prepared to occupy the position of 'rising man', i.e. accepting the challenge of ever higher levels of decision-making, generally welcome the expansion of opportunities, but those who, by reason of their situation (perhaps their unresolved problems in life), feel their existence jeopardized, try to put strong brakes on the advance of mechanization, often indulging in "pseudo-socialist" rhetoric to that end" (Sós, 1984).

The social and cultural effects directly attributed to the application of new technologies based on microelectronics are treated more differentially by those who speak of a "new model of production" (Kern/Schumann, 1984), pointing out that the earlier models of the division of labour and specialization are called into question even as regards the efficiency of capital utilization and that the role of qualification is upgraded in the advanced sectors of production (manufacture of automobiles and machine tools, chemical industry). The substance of highly influential postindustrial approaches consists in showing that, given the increasing sophistication of new production technologies, the appropriate operation of the production apparatus requires workers to reinforce their commit- 
ment and to acquire higher levels of skill and requires management to abandon the practice of restricting the utilization of workforce abilities. However, approaches of this type ' suggest that the very emergence of new technologies is bound to evolve new sets of social relations (Riesman, 1981).

In the course of debates, rather strong objections were formulated to the neo-deterministic views. One class of objections relates to the interpretation and measurement of qualification (Bernier-Cailloux, 1985). Analyses of the relationship between qualification and new technologies often use identical terms to designate quite different processes. A most frequent source of confusion is the failure to differentiate between the formal and substantive aspects of qualification. The formal and quantifiable criteria indicate the level of workforce qualification (schooling, education, practice) and support descriptive analyses of workforce structures, with the typical questions formulated in the following way: "What occupations are needed? What occupations are to be expected to disappear? What professional requirements are raised by an effective operation of different forms of new technology? What system of training is able to turn out labour of the required structure?"

On the other hand, the substantive criteria of qualification refer to the pattern (structure) of the tasks actually performed, with the questions formulated trying to grasp the degree of specialization of the tasks and the totality of aptitudes and skills required by the work tasks. The following combination of activities, for instance, proved to be of advantage in identifying the substantive dimensions of qualification in the analysis of the relationship between technologies and qualification (Simonyi, 1987a):

1. Transformation of objects and materials,

2. Treatment and transformation of information,

3. Operative activities,

4. Tasks involving the managing and organizing of cooperation.

However, similar research on automation or on new work organizations during the 1960 s and the 1970 s has disclosed the role of transmission played by the aspirations of the enterprise management and of the workforce and their conflicting interests. The fact that, along with techno-

1 The idealizing and simplifying predictions connected with such characteristics of the so-called second industrial revolution of post-industrial society as the rapid spread of industrial robots, the appearance of computer integrated management systems and the increasing use of $\mathrm{NC/CNC}$ technologies and with their social impact can best be likened to the neverfulfilling prophecies of futurologists of the 1950s concerning automation (Riesman, 1981: 285-302). 
logical development "governed by its own laws" and even conditioned by the management models of labour utilization, the mechanisms and traditions of managers' selection and the specific features of the internal and external labour markets bear considerable influence on the way the skills and experience of workforce are used (Braczyk, 1984). During the introduction and spread of new technologies, the values and endeavours of designers coincide with the ideas of the enterprise management and employees. Organizational bargainings, negotiations, and processes of interest representation going on in different institutional settings - embedded as in concrete sets of socio-political relations and following different models of cooperation - are shaping new patterns of work, responsibility and distribution of power. The following statement by a professor of the University of California concurs with the experience of many: "The power structure of the organization which provides an environment for the operation of information technologies does not tend to change in the short run and can only be supposed to change even in the long run" (Spitzchen, 1986: 3).

Research in Hungary, too, has shown that the new technologies integrated into the traditional enterprise organization have not evolved a more up-to date pattern in the division of labour: skills and control of the labour process have been produced along the former power structures and have thereby failed to lead to new, economically more efficient uses of labour and to bring about an organizational consensus for greater social advantage (Nagy, 1987). However, where information technologies had been integrated into enterprise structures that have traditionally recognized special skills and practice and have long provided strong incentives for their utilization (e.g. at VOLVO of Sweden or Scandinavian Airlines/ SAS), ${ }^{2}$, it became possible even in a shorter period to profit from the human and organizational advantages of technological innovations (Holtback, 1988: Edström, 1988).

The sceptics about predictions of the "end of the division of labour" raise even the problem concerning the scope of the new production models. For the time being, some studies have found certain new models of labour utilization operating in the central and economically strong

2 Ever since it was established (in 1924), Volvo has based its continuous and systematic technological and organizational innovations on the fact that both the management and workers, together with their institutional representation (the activities of Swedish trade unions have been legally recognized since 1930), have supported and highly appreciated the acquisition and the utilization of professional knowledge and expertise. The strategy to obtain quality utilizing human resources is represented by enterprise management and trade unions alike (Holtback, 1988: 4-5). 
sectors in the advanced capitalist countries, but there exists no reliable empirical basis for generalizations even in those sectors. At the same time, management and labour endeavours to establish new structures of work and cooperation can be observed also in declining industrial sectors. Such endeavours are able to surface in some cases, e.g. through decentralization or internal undertakings, and to result, even formally, in new models of labour utilization and cooperation (Berki/Makó, 1986; Neumann, 1988; Neumann/Simonyi, 1988; Kasvio, 1986; Dubois/Makó, 1988). In other cases, however, under conditions of "enforced innovation" or "enforced autonomy", the forms of cooperation and labour utilization tolerated but not legitimized by the enterprises remain concealed in the world of formalities, generating contradictory social and economic consequences (Fazekas, 1980; Laki, 1984; 1985; Ladó/Tóth, 1982; 1985).

In addition to flexible forms of work organization attributed to new technologies and to the upgrading of skills in the leading sectors of industry, reference should be made to trends detected in other spheres of the economy. Rather different social and organizational developments can also be observed in numerous areas of services. The organization of work in the spirit of the Taylorian and Fordian organizational techniques is spreading in, among others, tourism, financial institutions and health care. Combinations of organizations designed to ensure a relatively rapid integration of labour requiring a minimum of qualification with new technologies are found with increasing frequency in the entertainment industry as well (Walton, 1985). At the same time, in the process of introducing technological and organizational innovations, the third sector has been strengthened and expanded by small businesses which, providing various technical, financial, marketing or legal services for the enterprises, have followed models radically different from those formerly evolved within the framework of large enterprises (Simonyi, 1987 b).

Thus, debates both before and during the 1980 s tend to support the experience that the emergence and spread of new technologies, organizational methods of innovative management and new models of labour use are processes far from being parallel and necessarily interlinked. On the other hand, it is justified to distinguish technical-technological and socialorganizational innovations as they are likely to force their way independently of each other.

Research findings and the lessons of scientific debates point, just as they did in the 1960s and the 1970 s, to social interrelationships that are wider than the man-machine and man-work organization relationships. Assessment of the substance of technical and organizational change in the labour process has been found even today to require a combined analysis of the operation of processes at the plant or enterprise level and in the social and economic institutions. The methods and theoretical frameworks of such a 
"complex analysis" are yet to be elaborated, however. Disclosure of wider interrelationships often leads to new determinism: to descriptive analyses of higher hierarchical levels above the enterprise "micro-world" or of the widening concentric spheres of the economic and social environments, contributing to both domains' decisive influence.

Studies during the 1970 s were started on a double track to deal with two sets of problems: industrial relations and representation of workers' interests, participation and shopfloor democracy on the one hand and the second, or black informal economy on the other. The line of research concerned with industrial relations analyzed enterprise processes, i.e. the political and legal possibilities, frameworks and limits of interest and power struggles relating to technological development projects, and revealed essential social interrelationships connected with political struggles. Whereas research on the second, or "black" economy, studied more thoroughly the relationships existing between enterprise processes and society and the economy outside the factory gate, regarding the interests and behaviours of both labour and management. At the same time, labour utilization as well as the possibilities and limits of technological and organizational change were analyzed in the context of the segmentation of the labour market.

Indeed, technological or organizational determinisms have been disproved by integrated analyses and assessments of the labour process and the set of industrial relations. Studies limited to relationships within the labour process could not explain, among others, why workers in Japanese large enterprises do not react with work stoppages or some form of restriction of output to managerial methods of increasing labour intensity, such as planning production with a minimum of workforce and stock (Dore, 1987). In Hungarian industrial practice, such methods would give rise to individual and collective action interrupting production rather than increase individual and collective performance and strengthen cooperation within the given group of workers. The lack of different reserves serving to secure the continuity of production would tend to strengthen the position of workers versus management (Simonyi, ed., 1983). Opposite managerial and labour reactions to identical phenomena affecting the labour process cannot be understood from the labour process alone, to understand them requires a combined analysis of the internal relations of the enterprise's organization and the social methods of resolving conflicts. In that process, however, the researcher cannot stop at tracing interest relations at the workplace and the outcome of power struggles back to the existing set of industrial relations, for in doing so he is lured into the trap of another determinism still wider than the technological or organizational ones. 
Such was the case in, e.g., the Italian trade union movement when in the early 1980s struggles were launched in defence of the workers' interests. Those struggles embraced the interests of a very narrow range of workers even within the industry, while developments in other social spheres beyond the world of labour (welfare system, regional arrangement) called for an institutional system of interest representation and a type of action different from the traditional trade union strategy.

Studies of extra-firm channels or action, research on the movement of the labour market and even analyses of family, cultural and community interlinkages of informal relations have all demonstrated that the means and methods of conflict management and the mechanisms destined for resolving conflicts are not confined to representative institutions established in the course of social struggles and/or out of political wisdom nor to forms of negotiations between social partners that are institutionalized and legally regulated. Individuals or social groups reacting in the context of a specific problem and of efficiency of their actions cannot be understood merely in their direct social space, i.e. in their immediate environment of action. But in relation to and in combination with the conditioning role of norms, patterns of behaviours, interests and possibilities or their representation existing in all other spheres of society. Reactions of different social groups are to be observed in several dimensions and carry social contents that cannot be interpreted in one single development model.

\section{Arising Theoretical Approaches of Social Changes - Different Regulations and the Articulation of Social Spaces}

Before discussing changes in the models of social and economic development, it is necessary to clarify certain terms, namely the category "regulation" as an expression for the means of policy makers to distinguish that from the notion of "regulatory mechanisms" which refer to the different forms of social dynamism for its own reproduction (Piore/Sabel, 1984; Bagnasco, 1985; Reynaud, 1980). Our aim is not the analysis and the systematisation of the methods or techniques of social policies. We suppose that the use of unclarified and often overlapping terms give rise to confusions that exclude understanding of the real nature of social changes, and hence leave no room for exploring the possibility and means of directing it. 


\section{The Notion of Regulation}

In Hungary the advocates of liberal economy, just as the technocrats of state dirigism, mostly fail to distinguish the regulatory activity of the State from social regulations through the complex interplay of social relations and human actions. On the contrary, French social scientists draw a distinction between "régulation" as denoting the self-regulation of different systems and "reglementation" as denoting state intervention.

In the most general sense, regulation, or "balancing mechanism" or "equilibration", means self-organization of a system. This term is used in several branches of sciences such as biology or thermodynamics. In sociology, it means the sum of correctives aimed at maintaining some organizational form of social reproduction (e.g. production, family, community). In contrast to biological or physical systems, social systems are more open, because the individual or group assessments about the social process influence and thus make the rules governing the pattern of social relations more "vulnerable". But paradoxically they serve to secure the specific adaptability of societies as well.

The notional confusion was further increased by the "deregulation movement" which started in the USA from the second part of the 1970s on and sought to restrain the role of the State in the economy. Under our sociological concept of regulation, greater or smaller reliance on regulation is not an object of movements or policies, for regulation is understood to mean objective mechanisms which evolve and operate in the field of social relations and cannot be characterized by quantitative terms. Deregulation as formulated in the ranks of employers and liberal intellectuals or in state administration on behalf of different interests or values was a reflection of the struggles to establish a new kind of balance between various regulatory mechanisms. In certain cases, it meant or may have meant efforts to ease trade union constraints in connection with employers' decisions or/and, in other cases, to reduce state intervention in the economy.

In our concept, regulation by legal means, for instance, may serve either to widen or to narrow the sphere of action of state direction. The pattern of active and conscious intervention by the State or other collective institutions, parties, associations or alliances can best be described by "regularization" as the equivalent of the French reglementation. In Hungary, for instance, the Act on Association and Assembly, which is designed to improve the system of political institutions, seeks to influence the systems operating in different spheres of society and to determine the limits, means and possibilities of intervention. Legislative activity of such intensity, which we understand as regularization, may mean either limiting or increasing the role of a social sphere, namely the State in our case, but it 
is most likely to reflect shifts in the emphasis on state policies, i.e. transformation, in our view, of one regulatory mechanism and its synchronization with the rest of the society's regulatory mechanisms. ${ }^{3}$

Confusion in analysing social and economic processes often stems from the fact that the exponents of both the market's self-correction and bureaucratic central direction blur the terms "regulation" and "regularization", namely societies' regulatory mechanisms as they appear in objective processes and regulation by the State, disregarding the fact that the regulatory activity of the State (regularization) is socially conditioned just as the emergence, functioning and economic regulatory functions of the markets are. ${ }^{4}$ (So the concern of analysis should not be with moves between the two extremes of the spectrum from "arbitrary intervention" to "spontaneous self-correction". This mistake confines analysis to dichotomies like "State or market" and "State and market", excluding from

3 Piore and Sabel distinguish two significant regulatory crises in the development of modern, mechanized industrial production. One is linked with the spread of large enterprises emerging at the end of the 19th century and with the Keynesian welfare state of the 1930s. The other, a less visible one, - in their view - cannot be simplified to the inequalities in incomes and in power coupled with industrial technology and the organizational system in industry. According to them, the second type of crisis is related to the choice of technology itself. Industrial technology cannot be deduced from the sole logic of science or from the technological requirements, but its birth and realisation, depend on the structure of the market of products and of services. However, market structures are influenced by basic political conditions like distribution of property rights and wealth.

Thus, in simplified terms, machines are not mere motors, but also mirrors of social development (Piore/Sabel, 1984). The social aspects of industrial innovations are highlighted by Tibor Kuczi as well: "Home-made small tractors and rotary hoes today have their regional peculiarities, just as the peasants' traditional implements have. He who fabricates a rotary hoe on a do-it-yourself basis today is most likely to choose one of the technical solutions known to local "experts", all the more so since those solutions may also have a certain local advantage (e.g. the possibility that metal component parts available in a nearby factory may be turned into ones of a rotary hoe or the accessibility of a piece of iron on the local market") (Kuczi, 1987).

4 This is particularly true under conditions of state socialism, which previously paid little or no attention to market forces operating as a resource-allocating mechanism. The emergence of a market economy is inconceivable without resolute and clear government measures. For instance, a lasting evolution and operation of market relations cannot be imagined without support for undertakings relying on the expertise and social traditions of potential entrepreneurs enjoying concessionary financial terms and conditions in establishing businesses, and without a network of educational and representative institutions. 
the scope of both political and scientific thinking the other social phenomena that reflect the influence of other social processes or regulatory mechanisms both in the functioning of the market and in the formulation of state policies.

If, on the other hand, one is compelled by facts to become aware of the unquestionable presence of mechanisms existing parallel to the market and state interventions, the autonomy of this different type of regulation, governed as it is by its own laws, is often disputed, accepted only in subordination to other social regulators, or as forming subsystems of, either the State's or the market's regulatory mechanisms. A case in point is the fact that, as often, the very spread of small undertakings is often seen as simply a rational managerial reaction seeking decentralization. Or in other context as a phenomenon brought about by state intervention through regulatory acts to create a "background industry", a "protective net" for employment, or means of easing wage constraints. Whereas studies of the specific features of cooperation between small undertakings or of zones of small enterprises found in different countries have disclosed special regulatory mechanisms, based on reciprocity of various small interlocking communities, family, ethnic and local. But this may also be illustrated by efforts to explain the organizational autonomy of large enterprises either by reactions to market conditions or by links to state policy or by a combination of both, failing to understand the varied social configuration of these autonomies, embedded as they are in historical, developmental and regional systems of relationships and often differing even within one and the same country. ${ }^{5}$

Though organizational sociology calls attention to this from time to time, economic sociology concerned with a comprehensive analysis of the economy is still experimenting to group the relationships between the "relative autonomy of organizations" and other social dimensions of the economy (Héthy/Makó, 1972, 1978; Butera, 1979; Gyenes/Rozgonyi, 1981). Similarly, regional studies have long disclosed the existence of local autonomies and their effects, and, indeed, the factors responsible for the socio-economic lag or the rapid progress of different regions cannot be understood solely in the context of state policies and/or market relations.

5 In connection with the changing mechanisms for market regulation Katalin Szabò calls attention to the category of "vegetative" regulation, a term coined by Kornai and Martos: "An important distinguishing mark of vegetative regulation consists in its local character, in its taking place largely within particular economic units or at most in the interactions of a few 'parallel' economic units (e.g. enterprises in contract with one another). According to the economists cited, the significance of such regulatory processes increases with the growth of economic units and with their 'direct dependence"' (Szabó, 1986: 129). 
For an interpretation of autonomous economic organizations at the regional level, the social shape of development is likewise to be subjected to a comprehensive analysis (Piore/Sabel, 1984; Sabel, 1987; Bagnasco, 1985; Trigilia, 1985; Becattini, 1985; Enyedi/Weldman, 1986).

A new theoretical approach to regulatory mechanism is called for not only by a scientific need to recognize the variety of regulations interacting in a heterogeneous society as set out above, but also by the necessity overcoming the schematism which, by exaggerating the importance of political intervention; overemphasizes hierarchical relations, the power of the "rulers" and the subordination of the ruled.

Under a technocratic approach, society's regulation is inconceivable without those who govern. Moreover, for the exponents of that approach, the State is the only "neutral regulator" standing above group interests, and they try to change customs interweaving social cooperation into instructions or directives. In their practice, directing activity occupies a higher rank of the hierarchy than the activity directed. At the enterprise level, they overestimate employers' or managers' room for action. Thus, in combination with other effects, this leads to the "lack of sense of reality among managers" (Crozier, 1987). To influence and to govern by regulations of course, one cannot avoid the dynamic and complex human and social relations, but this cannot mean, nor does it objectively mean in view of the facts and historical processes, the actual dominance of a single type of regulation such as state regulation or its bureaucratic centralized variant alone.

Our concept of regulatory mechanisms operating in different spheres of society and the economy is not without precedent in Hungarian literature. Gyula Teller's categories of mechanisms, such as those of command economy, market and ideological integration (Teller, 1985), can be used to great advantage in interpreting the nature of the Hungarian cooperative movement. Jànos Kornai's distinction of the types of market, ethical and altruistic coordination has offered a new perspective for analysis in understanding the nature of economic systems (Kornai, 1980; 1983). His types of regulation conceived in other categories are close to Kàroly Polànyi's method of analyzing forms of economic integration as applied to understanding how social unity and stability are maintained through change: "The basic schemes capable of empirical discovery are constituted by reciprocity, redistribution and commodity exchange. Reciprocity is indicative of movements between mutually appropriate points of symmetric groupings, redistribution refers to movements of expropriation directed toward a centre and then starting therefrom, exchange relates to two-way movements between "persons" of a market system. ... As can be seen, different schemes of integration presuppose different institutional formations" (Polànyi, 1976: 241). Proceeding from Polànyi's regulators, 
Robert Manchin and Ivàn Szelènyi try to describe modern societies by various combinations of the market and redistributive schemes (Manchin/ Szelènyi, 1988).

A. Bagnasco, the Italian sociologist, distinguishes four main mechanisms for the regulation of economic activities. The first is held to be reciprocity, which regulates economic cooperation in family relations, relations of friendship and logical communities, such as dwelling construction under self-help schemes The second regulatory mechanism is deemed to be the market emerging in specific relations of production. The third mechanism emerges within large industry organizations to eliminate market uncertainties and is manifest in the relative autonomy of organizations. The fourth regulatory mechanism is political, or state intervention aiming to offset the negative social impacts of the market, including the rigidity of the labour market. In Bagnasco's analysis, the regulatory mechanisms of the large enterprise and political intervention during the crisis of the 1970s showed signs of exhaustion like the stiffening of hierarchies, the lack of motivation of economic actors, and delays in conflict management. The decentralization of large enterprises is thus seen as an effort to enhance the role of market mechanisms in regulating society and the economy, while there is also evidence of deregulation or regulation within enterprise organizations, whereas the specific autonomous system of relations in small enterprises is seen to be governed by a mix of the market regulation and the regulation in small communities on the basis of reciprocity (Bagnasco, 1985).

\section{An Integrative Analysis of Social Change}

Both empirical and theoretical analyses of the regulators that condition the different forms of individual and collective actions offer the general lesson that the substance and components of social phenomena cannot be grasped in subordination to a single "rationality", a single "social regulatory principle" or a dominant "regulatory mechanism". This means further that there may coexist, in time and space, structures, values and behaviours of cooperation which, by the nature of regulations, belong to different forms of social and economic institutions. Therefore society should be viewed in its complexity, as a heterogeneous and segmented formation rather than as a unit following a continual and trendlike course of development.

In their motion and change, the different formations overlap and may strengthen or weaken one another's social reproductive force and economic efficiency. The fact, for instance, that technological or production innovations do not by themselves determine either the new forms of work 
organization or a new consciousness of identity or new patterns of behaviour is susceptible of such interpretation. As concerns innovations, if they make their effects felt in only one sphere or in just one segment of an organization, the results of change are to be weakened just as they are likely to be strengthened if they are able to embrace different other dimensions operating under various logics within organizations (Butera, 1984). Similarly, this helps us understand why the development of work organizations as observed in industrial practice shows a diversity of relationships in the division of labour and in specialization. Accordingly, attempts at categorisation to identify change in the world of industrial work with the traditional or modernized forms of Taylorism or Fordism/ neo-Fordism or post-Taylorism/-Fordism are prone to misleading simplification in the description of production systems. The efforts at a general and overall interpretation of the development of the labour process were called into question by the differences revealed by industrial sociology research under the differentiating impact of cultural and ideological interrelationships (Maurice, 1988; Kasvio, 1985). Regardless of whether one considers state interventions/normative instructions, incentive policy, etc (or market effects) labour demand or supply, shortage, etc., no direct link can be established in the different manifestations of workplace behaviour (level of performance, innovation, cooperation, etc.). Research has disclosed an often determinant role of transmission professional and cultural traditions local and workplace "informal" relations.

As early as the first decades of this century, research concentrating on the functioning and practice of enterprises called attention to the role of informal organizations. This trend of research prevailed in schools of organizational sociology, whose best known followers include Crozier of France or Etzioni of USA (Crozier, 1981; Etzioni, 1975; Gross/Etzioni, 1985). During the 1960 s several Hungarian studies tried to extend analysis to social and organizational factors exercising influence on work performance. Such empirically based studies clearly affirmed the inability of structures of the official organization and management to have overall influence on such forms of individual and collective behaviour as work performance (Héthy/Makò, 1972; Kertesi/Sziráczki, 1983; Kövàri, 1984).

Later the 1970s witnessed, in both Hungarian and foreign research projects, attempts to systemize broader social interrelationships influencing the reproduction of the enterprise organization, going beyond the scope of the duality's of official-unofficial organization and seeking to gain a better understanding thereof (Köllö, 1981). Some of those attempts laid emphasis on the role of cultural and historical variables, called "effect societal approach" by M. Maurice ${ }^{6}$ (Maurice/Sellier/Silvestre, 1986), while

6 The term "social effect" (effet sociétal) denotes a sociological approach which 
others made a combined analysis of the labour process and industrial relations (Dohse/Jürgen/Malsch, 1987). It was among the advocates, holding different political views, of such approaches to research that the so-called labour process dispute, one of the debates in labour sociology that found the greatest echo, came unfolding from the second part of the 1970s (Wood, 1982; Buitelaar, 1988).

The main scientific result of this line of research consists, in our view, in calling attention to the political dimensions of social reproduction in connection with control exercised in the labour process. It similarly demonstrated the fact, that the emergence and persistence of principles governing human cooperation in the labour process are linked to the political sphere through an independent system of institutions and relationships, such as values, norms and traditions. The related studies brought into focus the internal heterogeneity of organizational relationships and the differentiation of environmental factors.

The drive for economic restructuring, from the mid-1970s on, raised with elementary force the need for understanding the mechanisms and conditions of social and organizational adaptation. Social sciences therefore tried to move in a direction that would allow interpretation and analysis of essential relations between organizational heterogeneity evolving in the course of adaptation and the differentiated "social fabric" providing a background for the former. In our view, this calls for the renewal of theoretical analysis not only to understand organizational heterogeneity and social differentiation but to identify and systematise "horizontal" relationships which generate and operate the former. The conceptual change consists not simply in the recognition of organizational and social diversity, but what we intend to make a core element of our approach is the need to survey the "pathways" between various social, organizational and cultural spaces in understanding the emerging opportunities for individual and collective action.

This need was formulated also with respect to organizational sociology. The use of new technologies, the changing requirements of qualification and the planned and natural modifications of work organizations made it urgently necessary to develop such a concept of organization that is apt not only to grasp interactions between an organization and its environ-

emphasizes the importance of interactions of social-organizational and cultural structures/spaces constituting the environment of different categories of "social actors" and their interactions.Under this approach, the contents and effects of relationships between technology and work, for instance, are transmitted by organizational and professional spaces in the entrepreneurial society. The diversity of these "spaces" is conditioned by the economic and social context in which the enterprises are functioning (Maurice, 1988). 
ment, but also to perceive links and overlaps between different internal levels, groups and strata within the organization, their interconnection by social relations, their linkages to extra-enterprise social spheres and institutions, and avenues people find for action. A growing number of enterprise case studies have accumulated ample experience, both in Hungary and abroad, of different (organizational, developmental and incentive) types of intervention which cannot be fitted into theoretical frameworks based on the duality of formal-informal organizations. But a more differentiated concept of organization is also needed for enterprise management, since their intervention can only succeed if they are able to establish, through the contemplated changes, a new equilibrium, a new type of cooperation within the organization, for which knowledge of intra-enterprise processes and sets of relationships is also indispensable.

Butera (1984) distinguishes seven coexistent dimensions overlapping to varying degrees, within industrial organizations, each segment having its own members and boundaries which do not always coincide with the organizational unit under review. Each of theses segments has its own internal coherent model, with different processes of communication, different arrangements for decision-making, negotiations and transactions, with different power groups and different ways of exercising their influence. Some segments are more developed than others in organizations belonging to different sectors and subserving different functions. This concept is capable of projecting a differentiated and complex set of social relations existing in work organizations, without resulting in a simplified uniformity. The organizational segments distinguished by Butera are the following:

1. The formal organization, which is the sum of instructions regulating the relations among members of a given unit and their activities. Through legal means, it legitimates the power of management. Its boundaries always coincide with those of the enterprise, but its influence varies widely in different organizations. In state institutions it is generally the dominant organizational segment, but in $\mathrm{R}+\mathrm{D}$ activities for example it influences only the smaller part of social processes.

2. The technical organization, which evolves in line with the rules of technical procedures in productive activities. It is sometimes wider sometimes narrower than the given enterprise, depending how far reaching are the effects of a particular cycle of work. According to Butera's concept, this organizational segment stems from technical power exercising its effects in a sphere varying between economic constraints, management normatives, cost ceilings and available resources. "This organizational segment enjoys the advantage that 
technical objectivity is legitimated by our society at a high level" (Butera, 1984: 242).

3. The "local representation" of institutions as an organizational segment may be illustrated by the intra-enterprise presence of professional communities. Thus this organization is the scene of activity of different social formations, e.g. an occupational group, following identical norms and values and governed by rules accepted as legitimate by a given social group. This segment comes into being on the basis of extra-enterprise norms within the organizations, e.g. rules, or habits of various trades such as lawyers, physicians, scientific research workers, organizers etc. Within certain organizations, dominant professions may exist whose norms may act as principal regulators of the organizations as, e.g., in the case of a research laboratory or a hospital. So what we have is not "local" rules, but "cosmopolitan" norms within an organization. In countries introducing new technologies on a wide scale, for instance, frequent mention is made of the "invisible college" of informaticians as an influential organizational segment reaching beyond the boundaries of their own enterprises.

4. The actual organization embraces such practices, operational procedures, rules and customs which, though unwritten, are clearly discernible and observed. This organizational segment is called into being by special local circumstances, traditions and professional experiences, its space is delimited by the flexibility of formal and technical organizations, it may be determinant in, e.g., maintenance or steel casting and rather limited on an assembly line. Its mostly invisible output becomes visible in cases of social and technical dysfunctions in the labour process. It is a segment regulating the ways to fulfil the tasks, the identification with roles, the flow of information, and the decisionmaking procedure alike. Its boundaries coincide with those of the given unit, professional competence being the main source of power in it.

5. The perceived organization, whose existence is based on the fact that groups with certain social and cultural attitudes form different judgements about organizations. The perceived organization is built of different subcultures, is composed of a series of coherent systems based on values, views and cultures. It makes its effect and determinant roles felt particularly at times of change, in the course of adaptation.

6. The informal organization, once defined by Butera in a much narrower sense than the generally held view, which so designates any organization born to attain another goal than the one officially institutionalized. By informal organization Butera means structures evolving in connection with the labour process and trying to influence certain special aspects of operation, structures that are not officially planned and whose norms, goals, membership and management differ from those of 
the formal organizations. Accordingly, he does not consider organizations whose sphere of activity goes beyond the scope of the labour process (e.g. cells of parties, trade unions) to form part of the segment of the informal organization.

7. The complex organization, which is integrating the various organizational segments, but represents more than their sum, ensures at the same time the internal coherence of the different segments. It is thus an expression of the "interplay" of different organizational segments jointly evolving the rules of behaviour that serve to cement technical and human resources together.

Thus, under this approach, the social process of organizational adaptation can be conceived as a series of cumulative changes taking place in the different organizational segments, in which innovations may be introduced, new sets of relationships may be forged and new managerial strategies may be articulated without alterations in the organizational model. At the same time, the positions, the relationships emerging in the various organizational segments as well as orientation among them allow workers to explore channels for their moves.

Similar conclusions have been drawn by several researchers engaged in network analyses. Granovetter, for instance, pointed out that the "weak ties" within networks established by strong ones in society and organizations are functioning as a "bridge" securing integration and mobility. On this basis he sees the channels for autonomous action on the part of the individual as belonging to several sets of relationships. "The fact that the individual is capable of meeting others' expectations at different times and places allows him to preserve an inner core, internal attitudes, while adapting himself to different expectations" (Granovetter, 1988: 41). Organizations that are both stable and innovative are described as constituting a system of sub-networks largely overlapping one another, with "a great number of weak ties performing a bridge-like function" between closer groups; so groups and cliques do not cut themselves from one another, but are open to receive and transmit informations and innovations (Granovetter, 1988: 51-55).

In recognizing, interpreting and exploiting the emerging or disappearing possibilities of acting, the individuals or their different social-organizational groups are oriented by their earlier experiences of treating social and organizational relationships during their "prior history". The formulation of strategies for individual and collective actions, or life strategies in the longer run, is based on professional, ideological and cultural values different in content, composition and level - emerging in the different types of learning processes. On the other hand, the processes of "professional" and "social" learning necessary for the mobilization of interest and 
the power relations that secure exploitation of the channels for action are far from following one another automatically. According to research experiences on social and organizational change, the "social appropriation" of the channels for action is more tiresome and more time-consuming and even more risky than the acquisition of professional competence. The explanation lies in the fact that the possibilities of acting are never influenced and shaped in a social vacuum and cannot be considered as a simple summary of individual actions, but a series of human and social interactions based on and presupposing collective knowledge. At the same time, exploiting the alternatives for action means mutual observance and acceptance of the "rules of the game" binding on the actors and influencing their manoeuvre (Makò, 1985: 108-109).

In the different forms in which human and social relations are organized, in the different social "spaces", the regulatory mechanisms exert their effects by transmitting values, norms and models generated by the experiences which social actors have gained and anticipate for the future, thereby influencing the form and direction of actions (Reynaud, 1980). This is an ulterior reason why changes taking place in technological, organizational and managerial systems do not mechanically alter the way of thinking of those concerned (managers, workers, employees) and do not directly determine the forms of treating the conflicts and the degree of organizational integration. The effect of change occurring in the sets of conditions for human cooperation within the enterprise organization, such as technology or the organizational, management structure are transmitted by the experiences of workers' socialization, by the traditions of management.

The problems of establishing cooperation in the process of production are obviously inseparable from the models used by partners, state, employers, employees, in industrial relations and from the general difficulties of changing the economic structure, and cannot be understood without them. Studying the mechanisms through which the system of industrial relations exerts its effects in enterprise organizations and labour processes without taking care of their changing patterns in time and space, amid different historical traditions and under different local conditions, can only take us to a broader determinism with the danger of generalization.

A natural presentation of interactions between the different social spheres is therefore insufficient. In each particular case, research should also inquire into what economic and political goals and socially accepted values are enhanced, upheld or set back by the mutually reinforcing or weakening mechanisms of the differed regulators of social relations, which combine to encourage or to hinder, through cooperating, the use of certain channels for action in cooperation. The "scientific imagination" of sociolo- 
gists is required to identify, among the most diverse attitudes capable of grasping the social, economic and organizational advantages of various types of change, the social differences between the mutations that might conserve, save, develop or surpass the existing structures. Even more, one must discover how these mutations are links to transformations in other social and economic spheres, in order to correctly interpret whether they result in social stability or merely serve to perpetuate a status quo pregnant with constraint.

In what follows we shall illustrate by some examples how this view of social heterogeneity and the regulatory mechanisms of society makes it understandable that individuals and the different groups of society are not "passive parties", but "real partners" in generating change. We shall try to illustrate the factors opening alternatives for autonomous actions for people living and acting under the conditioning but not determining effects of different structures, thus preserving and renewing, by their constant adaptation, social continuity.

\section{Managing Adaptation and the Autonomy of Actors}

Next we shall outline ways through which the supportive, resisting, opposing or indifferent attitudes of the agents of social, economic and organizational change influence the results of collective action, namely how people living, moving and acting in different forms of social institutions like families, small communities, regions, enterprises and political organizations, bring about the networks through which they are capable of responding to challenges of different types.

The most prominent network analysts, too, expect their methods and theory to move away from a static analysis of the sets of relationships to "a more methodological description of how such relationships develop and change. It is only by devoting greater attention to the problem of dynamism that social network analysis can fulfil its promises to be an efficient means of analyzing social life." (Granovetter, 1988: 60) The examples will illustrate our concept that the governability of social-organizational change cannot be imagined in terms of only one formation, however thoroughly analyzed it may be. This means that the scope for action by the agents of social change - those governing and governed may be limited in a given sphere, but may also be widened in time and space, by the diversity of society's regulatory mechanisms.

The success of efforts at modernization and of reform endeavours is also largely dependent on the extent to which the activity of those managing 
and regulating changes can be brought into line with the self-regulating mechanisms of society, on the extent to which hidden sets of social relationships brought into action against this or that type of regulating intervention or, on the contrary, to intensify this or that type of intervention are recognized and separated from one another, and on what social forces can be expected to follow or to suppress which values. Here we refer, not to a schematic "process from below", but to the fact that those governing a society, its reformers and modernizers have the joint, if not shared, task to recognize the move of society, the forms of social movements and to open room for utilizing social resources embodied in human expertise, organizational experience and cooperation.

\section{Search for Alternatives in Different Spaces}

In response to the requirements of increased competition in the industrialized countries since the mid-1970s, higher quality and more adaptive production, more economical use of materials and energy, more varied and flexible use of labour have risen to be new goals which the existing social mechanisms, though functioning relatively well, proved incapable of attaining. The reactions of capitalist countries in the sphere of economic policy, the changes in industrial structures and technological development projects in the second part of the decade, have testified not simply of economic or industrial adaptation, but also of the crisis, transformation and possibilities for renewal of the social mechanisms regulating social cooperation earlier.

The search for alternatives is under way in different spheres of society. State economic policy is one such sphere of the social processes of adaptation. The economic crisis urged national States, governments and political institutions to evaluate their economic policy priorities. The social problems calling for and attending economic adaptation appeared in the political scene with elementary force. Both employers and employees tried to assert their interests in economic policy shifts through their representative and political organizations. It would be a mistake, however, to attribute the successful economic adaptation of the advanced capitalist countries to the retreat of trade unions under the pressure of market conditions, and to the strengthening position of employers or to believe that the economic policy shifts and their substantiation resulted solely from the struggles waged in the political sphere.

The changes taking place in the highly industrialized countries, the appearance and rapid spread of new technologies, the phenomenon of productive decentralization, the revival of modern small plants and businesses, are rooted in the 1960 s, sprouted from employer and employee 
strategies called forth by the need for social renewal in that period, and were accomplished with incipient shifts in industrial relations, through numerous contradictions and socio-political clashes, with social movements full of strains resulting in the loss and recovery of advantages under the economic pressure growing from the mid-1970s. The economic requirements of adaptation were formulated during the crisis of the $1970 \mathrm{~s}$, but its social requirements had been expressed already by the movements of the late 1960s (Touraine, 1968). The alternatives of adaptation can only be regarded as successful if they ensure not only recovery from the economic crisis, but, in the longer run, the renewal of the patterns of industrial production and the lasting and long-term possibilities of acting for employees and employers as well as their widening.

It is in various directions, i.e. in favourably influencing state policies, in renewing productive, financing and marketing structures and in changing the sets of relations affecting the labour market (technology, organization, division of labour) that enterprise management is seeking ways and means of flexible adaptation. ${ }^{7}$ Technical-technological social and organizational

7 Until the mid-1970s, when the world economic crisis reached an international dimension, the flexibility of manpower utilisation had not been regarded as a priority issue by the social actors of industrial relations at different levels and types of bargaining. It is therefore not accidental that the notion of flexibility, referred to as a slogan in the present economic practice, is still unclarified. We should like to draw attention to the individual and structural dimensions of its study and interpretation. The former dimension refers to the ability, qualification and aptitude of manpower, while the latter means the complex of economic, social, political and cultural conditions assisting or impeding acquisition, utilization or mobility of the personal characteristics enumerated. Also, we wish to stress that flexibility in certain characteristics of manpower utilization (job mobility, performance of work on the basis of commitment and initiative) not only fits in but also presupposes the stability of other aspects of employment and manpower utilization (guarantees for employment, prospects for promotion, etc.; Bruno, 1986). The flexibility of manpower utilization and the security of employment are methods far from mutually exclusive; their combined application is clearly noticeable in the present-day practice of enterprise management. On this score, we agree with the statement that "... functional flexibility presupposes basic job security, but requires employees to be prepared to change job and occupation if necessary. In many countries, notably in Europe, obstacles to internal mobility are no less serious than those to external mobility. Rules governing functional changes, the absence of effective arrangements for re-training, and attitudes which are characterised by fear of change combine to bring about internal rigidities which prevent both technological and structural adjustment. The problem is above all European: in Japan, functional mobility in large firms is pronounced, and in the United States, to the 
innovations point in two directions. On the one hand, they renew mass production, the hitherto dominant production model in the highly industrialized countries, and make it capable of adaptation. On the other hand, with the strengthening of small plants and businesses, these marginal productive organizations formally in the background result in a new alternative model. The two directions appear interwoven in degrees varying by country and industry. The development or modernization of the existing mass production model through the introduction of high technologies is based on technological innovations, on various enterprise and work organization reforms experimented during the 1970 s, and on increasing workers' responsibility and commitment to the enterprise through new norms of cooperation between employers and employees.

In several industries from the motor to the garment industry, these efforts are also linked to global enterprise strategies ${ }^{8}$ which ensure both the reduction of costs and the organizational and social flexibility of production by making use of the possibilities inherent in the international division of labour (Fröbel/Heinrichs/Kreye, 1980).

Whereas earlier, until the early 1970 s, work organization reforms were aimed at softening up rigid automation, the high technologies spreading from the mid-1970s onwards have allowed scope for both technological and organizational flexibility. ${ }^{9}$ However, considering that micro-electron-

extent that is absent it is compensated by external mobility. In Europe, this may well be one of the two or three major issues" (Dahrendorf, 1986: 16).

8 The so-called World Car model can be summarized in the following: the car is designed in few centres, but manufacturing is organized in newly industrialized developing countries. This model entails the liquidation of a considerable number of jobs in the traditional car-making centres, with a parallel concentration of unskilled jobs in countries like Spain, Mexico or Korea. The efforts of enterprise management in developing countries to gain control of the markets however hinders implementation of the outlined development strategy of the car industry, where Fordism was born, as an extremely competitive, international industry. These efforts set a limit, by raising the level of qualification of the workforce in the developing countries, to unlimited exportation of jobs requiring minimum skills. (Wood, S., 1988)

9 The neo-Fordist or neo-Taylorist experiments of mass-producing large enterprises seeking flexibility and invariably keeping adaptation, technologically and/or bureaucratically, in the hands of enterprise management include:

- flexible automation through application of microelectronics

- computerized systems (CAD-CAM, CIM, CIMS) capable to assure changes of different parameters of the products in a minimum time, modifying overall processes from design to manufacturing.

- organizational innovations which, in the case of more or less rigid technologies, try to meet special and rapidly changing market demands by management methods (varied forms of autonomous groups of workers - QC, TQC, 
ics and computerization laid the technological groundworks for productive processes flexible by themselves, the organizations built on a rigid division of labour were also able to become efficient by new standards (Maurice, 1986). Indeed, labour processes based on flexible technologies can also be integrated into hierarchical, authoritarian large-enterprise structures as is illustrated by the FIAT of Italy, and at the same time, they have come to form the basis of flexible organizations and systems of autonomous work units such as "satellite" enterprises or networks of small businesses (Simonyi, 1987).

In our days, however, we can also witness, in a wider area than the leading branches of solid capital, the emergence of a production model differing from what is allowed by the technological-organizational renewal in mass-production within the large-enterprise organizations. Under a worsening set of economic conditions, the adaptation of large enterprises excludes some segments of labour from mass-production, other groups reject the prospects opened by change, yet others rely on their experience for improving their positions. The different segments, guided as they are by various motives, find work, means of living and perspective in previously hidden forms of production. Models of production like small plants and small businesses, which had been consigned to oblivion by massproduction, became widely "reusable" under the altered conditions of the economic crisis and in a different technical-technological environment.

With the reform of the existing organizations of mass-production in the big firms, the partly spontaneous, partly state-supported revival of the system of small enterprises, which for a long time had been regarded as outmoded, contributed - in degrees varying by country, to the stabilization of the economic situation and the success of adaptation in all advanced capitalist countries. This alternative in industry is also encouraged by technical progress based on micro-electronics and by the technical possibility for efficient production in small series independent of the size of enterprises. Given the change in workers' demands and the need for larger autonomy and more complex work tasks, industrial development has also accumulated considerable professional and practical knowledge as well as organizational and social experience in the affirmation of interests in some segments of workers. All this combined not only to create conditions for innovative economic adaptation in the sphere of small plants, but also to renew the human and social relations of production.

etc. - developed to increase workers' autonomy based on individual and collective participation). 
Rediscovering Localism as a Special Regulatory Mechanisms: The Case of Central Italy

In some analyses, it is regarded as almost automatic how mass-production in the large enterprises has regained its lost flexibility by decentralizing and avoiding trade union pressure, "organizational structures ... which, once evolved, will be able to secure enterprise flexibility" (Dallago, 1988). However, neither the revival of autonomous, independent small enterprises producing for the market nor the network of small enterprises established by large companies or producing on their orders can be considered simply as automatic responses to changes in the world market of the 1970 s, nor can they be produced by a single administrative act, as is shown by, among others, the existing results of Soviet measures (Gorbachev, 1987). The development of the sphere of small enterprises from China to Japan and from Italy to the United States has its roots in longer social and political processes and has also needed specific social conditions and lasting and manifold political support everywhere.

The "industrial districts" of Middle Italy may be cited as good examples to study the model of industrial production differing from that of large enterprises not only in terms of work organization and enterprise structure, but also in the pattern of social relations. The term "industrial districts" as used here is not identical with that of industrial regions showing a concentration of large industrial enterprises and revealing dissimilarities rather than similarities to industrial regions like the Ruhr region, Manchester and environs, or Milan and environs. It is more like the classical concept which Charles Sabel recalls in these words:

"Until the middle of the 19th century, a region was the self-evident centre of economic activities and analyses. Sheffield and Solingen were noted for their knifes, Lyon for its silk, Birmingham and St. Etienne for their firearms. ... For consumers, a product was denoted by its 'origin', its place of production, rather than by the enterprise" (Sabel, 1987: 7).

Here are a few Mid-Italian examples in illustration of their revival in the 20th century: half the quantity of carded textiles produced in the Common Market is made by a total workforce of 50,000 , in textile workshops with a staff of 5 on average, in and around the city of Prato in the Province of Toscana. A firm in the Province of Emilia turns out 5,000 motorcycles a year from a workshop employing as little as 100 workers and subcontracting with dozens of smaller workshops. The plants of Reggio Emilia manufacturing fruit-collecting machines employ over 10,000 workers, but the number of workers exceeds 500 in only two firms. The Benetton firm in the Province of Veneto owes its worldwide reputation to its own staff of 1,200 to 1,300 workers while incorporating, through a network of home- 
workers and subcontractors, the labour of the region's 10,000 to 12,000 people into its products.

In those regions, where a small town or a chain of them specializes itself in one or two products or one or two industrial branches, the local economy is capable of growth by simply using the method of following or copying others. To be launched, an undertaking requires a small amount of capital input, because know-how is familiar to local people. Growth results not from the swelling of a firm, but from outward expansion, from an increase in the number of production units, a special means of reaching an optimal size of series. Accordingly, in larger enterprises organizing the production cycle and turning out the finished products, production takes place in complex, labour-saving systems of smaller enterprises producing with modern machinery (NC lathes or laser-based sewing machines), with a simpler administrative apparatus, which allows for the integration of local labour in the most diverse forms of employment.

There are two historical peculiarities that help us understand this type of Mid-Italian development: first, the centuries-old urbanization, which acted to spread industrial, commercial, financial and cultural traditions to wider regions, and, second, the spread of autonomous forms of agricultural production, i.e. métayage and small plants that evolved within it.

The basic unit of the agrarian small plant of the métayage type was the family, which was, for the most part, "large enough to form an organization capable to control its own life and autonomous enough to experiment with innovative and organizational abilities; it lasted long enough to see the changing conditions of general development, thus releasing labour for the labour market and compensating its members switching to industrial trades for the initially low and irregular earnings" (Bagnasco, 1987: 41). Within this system, the head of the family has been in charge of rationally distributing time, energies and the activities of family members while minimizing losses and risks.

During the 1960s and the 1970 s, the families with a more differentiated pattern of internal relationships, in which one member was perhaps still engaged mostly in agriculture, but together with the younger ones with their already acquired secondary or higher schools, were able not only to provide a state background for their members or to compensate them for the eventually irregular earnings, but to function at a higher level as independent entrepreneurial units. These families were able to pool human and material resources in such a way as to create the financial and organizational basis of independent small undertakings. ${ }^{10}$

10 The possibility of tax evasion, allowing increases in income available for consumption, naturally formed part, but was not the only motive, of this effort (Dallago, 1988). As against redistribution of incomes uncontrollable by politi- 
Another factor along with the existence of needs, traditions, infrastructural and social conditions relating to work and its organization, a factor decisive for the survival and then responsible for the growing momentum of small undertakings in Central Italy, was that the Italian national market was not rebuilt through the standardization of the various local needs; subsisting with mass-production, expanding capacities remained to supply a variety of traditional internal needs and to meet the differentiated demands of foreign markets. This is well illustrated by the light industry, the constructing materials industry or the manufacturing of vehicles in Italy (Piore/Sabel, 1984; Simonyi, 1987).

All this had its effects on the coexistence of enterprises differing by size and organizations. When the vertically integrated large organizations, producing series of uniform products, came to be incompetitive, entrepreneurs, middlemen, merchants and workers gradually switched to production based on a technological optimization and decentralization of the different phases of production. The new units neither followed previous models of production nor imitated their parent companies, but became specialized in some phases of production or its services. This arrangement resulted in efficiency gains for new firms and saved costs for existing ones. Hundreds and thousands of small and medium-sized companies in Central Italy, occasionally linked to their "parent companies", apparently did the impossible: turned out mass products, yet diversified from time to time for large oligopolistic markets.

All this is a network of intermediators and merchants reaching all producers and keeping them as well as collaborators and buyers fully informed of demands, requirements, capacities and possibilities alike. It was that network which was capable of canalizing the products of decentralized, dispersed productive networks towards the national and international markets and of ensuring optimal series of production in the given unit (town or district). The emergence in this way of industrial zones would naturally have been inconceivable without the rapid development of transport, roads and vehicles as well as communication facilities.

As against this type of industrialization, frequent references are made to the vulnerability of the system of small businesses, the lack of a stable big industry, the preponderance of traditional industrial branches, and the exploitation through "blackwork". This reasoning is mistaken when it does not consider an "industrial zone" as a "territorial system of enterprises", as an integral unity. The term "territorial system" refers to the characteristic of the network of small firms in a given zone, capable of

cal means, it left room for retaining resources for local employment and development, but local societies kept their influence on them, even though by other than formalized means. 
surviving and developing regardless of possible uncertainties about its component elements. Security means not only the survival of an industrial branch, but also the fact that the eventual failure of one or another enterprise does not leave either the entrepreneur or his employees without means of subsistence, because they can find jobs appropriate to their practice and qualification at other units in the zone (Sabel, 1987; Ekstedt/Henning, 1988).

The social relations of Italian regions following this line of development are usually described as having a low degree of polarization, which is understood to mean partly the lack of classical proletarian masses in the big industry, partly less sharp dividing lines and a high-level mobility between segments. "There is no sharp difference in attitudes between workers and employers, family ties are frequent, and careers are open both ways, with the attitude towards work acquired in craftsmanship and in family arming encouraging people to seek cooperation" (Fua/Zacchia, 1983: 18)

Cutting through the not too marked class-structure, the catholic and socialist movements which had developed in these regions since the end of the last century embraced wider community dimensions. In the phraseology of network analysis we might say that the different social segments and groups in these regions of Central Italy are bound together by numerous "weak ties", which make it possible to maintain and exploit close local community and family relations in such a way that these communities are not isolated from other social groups nor cut off from their informations, ideas and innovations. "Small groups active in spreading culture are not so coherent as to be completely closed, but rather they are penetrated with ideas of other groups through weak ties" (Granovetter, 1988: 50). Thus the close social bonds and the "weak ties" of overlapping networks were together capable of stabilizing and renewing the societies and economies of these regions.

Since the beginning of capitalist development, the "subcultures" of Central Italy have served to protect local societies partly from the market, partly from the central government or the State by trying to restrict social disintegration and emigration and to influence local relations ensuring industrialization without sharper conflicts and without compelling inhabitants to move to other regions (Ascoli/Catanzaro, 1987; Trigilia, 1986).

A common political feature of the Italian regions where small businesses are preponderant is the fact that, by the force of specific political traditions, local affairs have been firmly controlled by the same forces for decades, namely by the Christian Democrats in the North-East and by the Communist Party allied with the socialists in Central Italy. Thus, governments which, unlike other regions of Italy, are not exposed to unstable coalitions often incapable of decision or implementing long-term concepts, 
facilitated, by both economic and political means, the so called "diffuse" industrialization based on the networks of artisans and small businesses, providing infrastructural facilities and thereby securing properly supplied regions for entrepreneurs, supporting vocational training, and helping to establish consortiums, cooperatives and other forms of cooperation for the marketing of local product and the strengthening of local cooperation.

Industrial representation of interests bears the characteristics of the specific social relations in these regions as well. The ratio of unionized workers in these provinces is the same as the national average, which did not exceed 40 percent of those employed even in the most successful years of trade union struggles and is about 30 percent at present. Understandably, it is not an aim of trade union activism to weaken local political relations, and local political direction is also strongly committed to early settlement of industrial conflicts to the advantage of both entrepreneurs and their employees. Social and political pragmatism calls into life widely different forms of production and representation of interests. Women homeworkers, for instance, have formed several homework co-operatives to control earnings and time and to get rid of middlemen.

Coordination of local interests owed its efficiency among others to the fact that most artisans and small entrepreneurs were also members of local chambers, so the local leadership did not have to intervene in individual cases, but could negotiate with committees of entrepreneurs. In order to win recognition and to have their material demands and their demands for classification in wage categories accepted, the trade unions agreed in most cases to ease restrictions on manpower utilization. At the same time, the local political organs often intervened with banks or government authorities to save bankrupt firms.

At the pole opposite to the network of small enterprises enjoying trade union "protection" are to be found the very small firms and artisan workshops, mainly with staffs of 3 to 10 , which were called into being and are maintained by large enterprise efforts at decentralisation. There the trade unions are not present and "there the industrial sector is able to redeem part of the costs incurred by trade union presence" (Trigilia, 1987: 230). At the same time, however, the family background and community constraints are able to lessen disadvantages in earnings and to reduce the irregularity of employment for people employed there. In this sector, mostly wives and children of organized workers employed at industrial enterprises are engaged. Thus, while the independent sphere of small enterprises gives rise to a specific type of local corporatism, the small firms and their employees dependent on large enterprises remain outside that sphere. Nevertheless, in view of local community and family relations as well as of channels for employment and mobility, this latter sphere cannot be interpreted in itself either, but in the context of local society as a whole, 
as a form reflecting specific workers' channels for the utilization and reproduction of human resources.

This path of economic development and adaptation has, with its own set of social conditions, called attention to the fact that, under the impact of the market's regulatory mechanisms and under the influence of state or managerial intervention, beside the rational interest of large enterprises, the world of small market, the State and the large enterprises, but follows a separate path of development in shaping individual and collective behaviours and "assimilating" community, market, state and political effect. Regulation of social and cooperative relationships based on reciprocal services can be observed in family or small community relations. Such regulations in turn, along with the regulatory mechanism of the market and state intervention, exercises an influence of its own and, in combination with the other two and mutually conditioning one another, provides a background and a perspective of action for the individual and collective actors of the economy, with advantages to technological and organizational development, economic adaptation and social reproduction. Within smaller communities, "local societies", the regulatory mechanism based on reciprocity is a specificity capable of appearing even in the political relations of local or regional direction, providing some scope for autonomy independent of national or state politics. Relying on this and assisted by local resources the local or regional direction is capable of becoming autonomous and taking charge of dealing independently with the economic and social problems of its own district.

The pressure for cooperation is direct at the local level and stronger than in nationwide party politics and in the state economic policy articulated through several transmissions and a more complicated institutional system. The characteristics of regionalism, regional social, economic, local and family traditions, give specific social substance even to market relations, to the norms, goals and tools of management, to the relationship of employers, entrepreneurs and workers, and to the functioning of the institutions of industrial relations.

At the same time, the described model of Italian industrialization, based on a network of small enterprises and called diffuse, undoubtedly affected Italian industrial relations in their entirety, though not immediately and directly, not to weaken workers' organization in the big industry. and the efficiency of representation of their interests, but rather by easing, through its growing vitality, the economic and social strains of Italy and considerably separating their treatment from an uncertain national consensus between trade unions and large enterprises. This model of production made it easier for the government and large enterprise management as well as for considerable segments of workers to find an intermediate arrangement between the coordination of interests at the national level, 
rather costly in social and economic terms, and the maintenance of social and economic strains threatening with consequences that were increasingly difficult to control from the mid-1970s onwards.

In the sphere of Central Italy's small enterprises neither employers nor trade unions were opposed to the coordinating of interests at national level and, whenever their interests so required, they even tried to replace local agreements by adjustments to central ones. In general, central agreements honouring social needs, demands for pay rise, and assignments to wage categories resulted in benefits to local trade unions. The situation changed somewhat from 1978, when, during the period of the policy of national solidarity proclaimed by the Left in the interest of combating terrorism and the economic crisis, the trade union centres called on workers to moderate their wage demands. Afterwards, central agreements provided protection for, e.g., entrepreneurs against local trade union demands which were out of line with, and even in excess of, the norms adopted by their own top organs.

Nevertheless, the existence of the small enterprise sphere, its mode of operation and described set of industrial relations were not inconsistent with efforts at renewing central bargaining. With its specific relations of cooperation and local regulatory mechanisms, the small enterprise sphere served to offset the economic and social disadvantages of inefficient and unstable agreements resulting from bargaining ${ }^{11}$, while calling the attention of both researchers and national, political leaders to the ability of society to mobilize, in giving responses of social adaptation to crises, such resources and cooperative mechanisms that cannot be substituted for either by means of state intervention or by "market coordination".

So what the state direction has to do is not only to redefine its role in respect to the market, but also to recognize and encourage political, economic and social innovative capacities inherent in local conditions.

11 At the same time, the system, institutions and regulatory mechanisms of national bargaining failed to be renewed in the longer run. The consequence is already visible: a reduction in employment in large enterprises that is increasingly difficult for the sphere of small enterprises to counterbalance. Moreover, even small enterprises would need support, exceeding by far the resources of local management, to ensure infrastructural, training, financial and other conditions for continued modernization. Therefore, Italian sociologists argue in favour of social and political reforms which, on the one hand, would allow the basic issues of the economy to be successfully influenced and the social and regional inequalities lessened by the means of a national policy while on the other hand the reforms could rely on political and economic innovative capacities inherent in local conditions (Butera, 1984; Reyneri, 1987; Bruno, 1986). 
The Process of Collective Learning in the Hungarian Enterprises: The Social Message of "Inside Contracting Groups"

During the past two decades Hungarian enterprises have exerted wideranging efforts at adaptation affecting smaller or larger masses of employees as regards the organizational set-up and managerial methods. The relevant initiatives came in part from central economic management organs, in part from enterprise management. Moreover, research conducted at enterprises found that several innovations, officially unproclaimed but tolerated, had been introduced in work organizations. Looking as far back as the early 1960 s, we can refer to various initiatives by economic management concerning drives for centralization and decentralization, encouragement of emulation and brigade movements, development of bargaining institutions, and measures to create wider possibilities for workers' participation in enterprise management (Voszka, 1988; Bogdán, 1981; Dózsa, 1971; Hèthy, 1983; Bossányi/Nyikos, 1987).

On the waves of these central measures but often independently of them, some enterprises set in motion processes of renewing structures of management and direction, several enterprises experimenting with, e.g., refining incentive systems, adopting techniques of organizing work and plants as applied in the highly industrialized countries, and introducing structures of wider workers' autonomy with a view to increasing workers' motivation (Horváth, 1975; Héthy/Makó, 1972; Nagy/Simonyi, 1982; Berki/Makó, 1988).

Parallel to these processes started by central and enterprise management, often in objection to or in support of them, various professional and occupational groups have themselves evolved specific forms of cooperation within the enterprises. We refer to the widespread practice of wage distribution replacing the official incentive system and based on independent decisions of team members, or to arrangements for the organization of work to eliminate the malfunctions of the official organization. Such spontaneous initiatives by workers have often led to technical-technological innovations, but have also demonstrated that some groups or segments of employees have a notable social ability to organize their interests or to influence decision-making (Laki, 1984-85; Farkas, 1983; Burawoy/Lukács, 1980; Makó/Simonyi, 1985).

As can be seen, the past period of two decades, characterized by swings in the economic reform (Tàrsadalmi Szemle, 1989), has witnessed diverse processes in the world of labour thus immensely enriching the individual and collective (technical-professional and social-organizational) experiences of their participants. After this sketchy outline of change induced by different motivations, we shall try to present a process typical of the $1980 \mathrm{~s}$ 
in order to illustrate the degree of autonomy that can be gained by collective action in the labour process. Initiated by the central economic organs and forming part of a package of programmes for small undertakings from the early 1980 s on, the changes that took place in the Hungarian system of enterprise management have offered lessons which must be reappraised and turned to good account in an effort to improve society's self-knowledge and guidance.

The greatest interest and dispute were aroused by "inside contracting groups" (hereinafter referred to as VGMKs, the Hungarian acronym), as one of the forms of undertakings authorized in 1982. It was for the first time in the history of four decades of Hungarian industrial practice that we could be witness to an organizational innovation, relatively well documented by empirical research, which was supported and moulded by nearly 200,000 employees and met with relative little opposition. In the mid-1980s, "... 11.5 percent of the full-timers in industry participated in VGMKs, but this ratio varies widely by sub-sector" (Neumann, 1987: 5). That initiative, mobilizing so large masses and relying increasingly on workers independent organizations, can perhaps be compared to the scale of ace-workers emulation or the socialist brigade movement (Kresalek, 1988: 206).

The "insider labour contracts" destined for overwork and relying on a greater autonomy of the participants in the organization of production and on increased inducements for their performance as compared with earnings on full-time jobs, are stated in most reports to have been a unilateral initiative of enterprise management for the integration of workforce: "a large part of the enterprises have switched to a purposive manpower management granting privileges for participation in VGMKs, to better qualified workers with a longer period of service in the enterprise and capable of better adjustment to local power apparatuses..." (Csillag, 1988: 52). This quotation is an adequate expression of the fact that enterprise management was willing to widen the scope of action for segments of workers playing a determinant role in the maintenance of its power ${ }^{12}$. In enterprise practice, such endeavours were induced not simply by a "willingness" for opening but by the pressing necessity for securing the order of the labour process, for organizing production.

12 What we have here is far from a new method of manpower utilization characteristic of enterprise management practice in our days (Friedman, 1977; Naville, 1971). The special positions enjoyed by some groups of employees in comparison with managers and other segments of workers allow for the former a relatively wide scope of independent action and initiative. All this might be, if not aimed at, impeding united action of the workers and dividing their ranks (Dubois, 1988). 
The considerable difference between groups of workers in terms of their position in production and local labour markets is well illustrated by glaring inequalities in admission to VGMKs. The possibilities to live with the different channels for action objectively present in the labour process could be largely facilitated by living in the same residential district or community as well as by belonging to the same ethnic and cultural affiliation (Hèthy/Makó, 1978).

Qualified workers had several times greater chances than unskilled ones to join a VGMK. In like manner, workers in the capital had considerably greater chances than those in a remote county, for instance (Berki, 1984). In early 1986 " ... more than half of VGMK members were skilled workers, 18 percent were semi-skilled, and 2 percent were unskilled" (Neumann, 1978: 14). Inequalities in admission to VGMKs can also naturally be observed in other important dimensions like length of service, sex, nature of jobs.

Autonomous action by groups of workers capable of collective action was appreciated or tolerated by enterprise management in Hungary, which used varied means of securing overwork, premia for special achievements and extra earning during the 1960s and the 1970s and could, in return, count upon support from different segments and groups of workers. Some groups of workers exercising nearly "self-managing" functions in the labour process played an almost irreplaceable role in the short term by performing even some functions of management and direction. To maintain the continuity of production, workers and particularly those belonging to the centre had to contribute a disproportionately large share to the organisation of the productive processes.

What is involved is naturally more than the unclear situation and functions of the enterprise techno-structure. It is a general feature of the Hungarian economic environment that "... enterprises, helpless as buyers, must apply special forms of adaptation even to ensure the manufacturing of their accustomed products by processes far from being continuous and regularly departing from production plans or programmes.

Given the known difficulties in materials supply, slackness in delivery and cooperation, quality problems, labour shortage and long deadlines for procurement of machinery, unprotected buyers try to improve their situation, to overcome their difficulties by a variety of means." (Laki, 1984-85: 46). These specific solutions, the so-called "enforced innovation" and "enforced autonomy" play a disproportionately large part in maintaining the continuity of production and thus upgrade the role of workshopspecific abilities and skills, technical-technological as well as cooperative. ${ }^{13}$

13 This is corroborated by research findings on the selective mechanisms of the economic management: "The chances of someone getting elected manager are 
Enterprise top management which failed to think in terms of making use of the "tacit knowledge" of the workforce and which underestimated the significance of human resources has regarded VGMKs as a means of promoting the fulfilment of targets (surplus production, export plans, etc.) and as global indicators of enterprise activity. The extra performance under "internal labour contracts" for overwork and the excellent quality of work done on schedule were explained very often by changes in planning and accounting techniques and by motivation for notable extra income payable from the productive cost funds. Consequently the "only" problem facing management concerned ways and means of easing social strains arising from the relationship between participants in VGMKs and workers remaining outside them. On the other hand, enterprise top management was less aware of changes occurring under the impact of VGMKs in the existing structures of management and direction.

With the introduction of VGMKs, "... management got rid of almost all human problems of directing production, particularly of performing functions, psychologically and socially the 'costliest', like the organization of work and the maintaining discipline at the workplace" (Makó, 1985: 62). Managers saw their workloads reduced even in quantitative terms, for VGMKs turned out products at less cost, in higher quality, and with more reliable planning than external cooperating partners did. Thus, plant and workshop managers daily facing technical and human difficulties in production became interested in the operation of VGMKs in the hope of, and with a view to, actually reducing these problems.

Owing to the decisive influence gained in determining tasks and concluding inside contracts, the existence of VGMKs gave even the major tool of inducement into the hands of lower and middle-level managers. As a result, there was a reduction in the burdens imposed on them by the need to finance from their own resources "workers' expected wages" under conditions of strict wage regulations and the bureaucratic system of

determined not so much by professional performance but rather by aptitude, tactical sense, ability of self-management, and criteria of loyalty" (Lengyel, 1984). Managers working at different levels and in different areas refrain from introducing radical change involving sharp conflicts. Efforts at "security" play a decisive role among the values of managerial action. Such a system of management and direction is characterized by "residual" change supplementing, correcting and "doubling" rather than questioning the organizational status quo. Taking this in consideration the introduction and functioning of internal subcontracting groups proved to be an ideal arrangement as they did not compel enterprise top management to take radical steps, to revamp the prevailing official structures. Instead "organizational reserves" were integrated into existing systems of management that served to put off radical change, but made it possible to secure flexibility indispensable in manpower utilization. 
motivation, while VGMKs themselves played a part in regulating wage rates within and among VGMKs and having them accepted by members.

The delegation of such important responsibilities in respect of stimulation, contingent as they were on compliance with contracts and acceptance of tasks on the "line of production", strengthened the position of production managers even in comparison with those of the functional sections of enterprise management. This rearrangement served to reinforce coalitions of interest between production managers and workers. The inside labour contracts for overwork might even be said to be "collective products" of groups of workers occupying a central position in the labour process and of cooperation between the workshop and plant management. ${ }^{14}$

Of course, the activity, composition and autonomy of VGMKs were rather varied as they emerged in work organizations, with strong differences in levels of technology and organization in the most diverse branches of industry. Thus there were marked, though varying, differences between the functioning of inside contracting groups formed for doing overwork and the logic of full-time work organizations. As contrasted with the practice characteristic of the latter, VGMK members select one another on the basis of actual abilities and aptitudes as well as of human qualities appreciated in smaller communities. It is often they who take care of ensuring coordination with the planning of production and other aspects of preparations therefore.

This means that in the VGMK practice of manpower utilization, patterns of behaviour and methods of cooperation which were not usually applied on full-time jobs, except in temporary and extraordinary situations, came into general use.

To build, operate, and explore a set of relations, differing from the clearly defined hierarchical organizational structure of full-time employment based on maximum specialization of individual jobs, required considerable efforts on the part of VGMK members, a large part of whom acquired in turn an "organizational aptitude" (culture), a logistical knowledge concerning the organization of production. That enabled them to compare, evaluate and criticize different models of the division of labour and human cooperation, namely those prevailing on full-time jobs. It was widely recognized, for example, that clear boundaries between certain

14 It is not only for economic considerations that lower- and middle-level management and the workshops' supervision find it essential to win the cooperation of the workforce important to ensure the smoothness of the labour process. As a supervisor put it on this score, "... we need qualified labour. Even if the homeworkers' cooperative is cheaper ..., the social aspect should also be taken into account in the case of VGMKs: workers are accustomed to have extra income" (Neumann, 1989). 
sectors of production (manufacture, internal material transport and handling, quality control, maintenance, programming) were only of administrative relevance and did not exist in reality. VGMK members organized their activities within organizational networks, integrating both horizontal and hierarchical relations different from those of the formal-hierarchical management system and within the frameworks of amorphous relationships of mutual dependence.

However, the operation of inside contracting groups, though governed by the principle of maximum trust, based on thinking in terms of the "entire" production process, professional skill, mutual allowance for one anothers' interests and aspirations, mutual tolerance of chances for action and thereby on stable rules of the game, is far from free of internal contradictions and strains.

The source of disagreements and differences of view was constituted primarily by assessment, qualification and treatment, before the publicity of the workshop and the plant, of attitudes manifesting themselves in questions of performance and income.

The professional-technical and social-managerial aptitudes of those collaborating in VGMKs - considering that they have been socialized in the diverse types of work and management cultures - have developed unevenly. In setting up inside contracting groups, the participants have selected with comparative ease their colleagues with appropriate professional competence and records of high performance, but the ability to "deal with" human relations has come to light with greater difficulty in the process of selection. The "visibility" of such aptitudes is made difficult by patterns of division of labour and socialization typical of full-time jobs. The so-called articulated type of cooperation in general use made it mostly superfluous for workers to help one another and to assume responsibility for their colleagues. The methods of wage determination and the prescriptions of performance requirements down to individual jobs made it difficult to recognize one another's aspirations and needs. Performances exceeding the scope of individual jobs and collective actions are needed only in critical situations, and the ability to have them recognized was possessed only by segments of workers with exceptionally strong positions in the labour process.

Thus collective autonomy became gradually legitimized, and the easening of direct dependence on the official managerial hierarchy threw into sharper relief the participants' ability to build and control human relations.

The collapse of several VGMKs, otherwise consisting of highly qualified members, can be explained by the unequal development of the participants' social knowledge or, put another way, organizational culture. 
There developed an instructive dispute between David Stark and László Neumann about the interpretation of the experiences concerning the operation of VGMKs and about the assessment of their social consequences. The American sociologist Stark looks on the formation and operation of VGMKs as a managerial initiative for reducing uncertainties arising from the bureaucratic environment by leaving the allocation of and inducements for the workforce to internal mechanisms basically governed by market principles:

"... in economies in which the firm operates in a market environment, systematic uncertainties regarding labour are reduced through internal bureaucratic rules, In the socialist economy, by contrast, where systematic uncertainties are produced by bureaucratic environment, the firm responds through internal market transactions.

The use of internal market transactions to reduce the effects of systematic uncertainties in the socialist firm is brought into sharper relief in a recent organizational innovation in Hungary - the formation of semi-autonomous subcontracting units inside the enterprise." (Stark, 1986: 493).

According to Neumann, however, the functioning of VGMKs cannot be understood as a mere phenomenon of the enterprise's internal labour market. On the basis of his research he pointed out that enterprise wage bargaining was governed by what he called coordinative mechanisms, as regards both the attitude of VGMK members and the actions of representatives at different levels of management, which "suppressed the classical price-regulating effects of the market". (Neumann, 1988: 65) His findings are noteworthy for the very reason that he conducted his inquiry in a large enterprise where VGMKs had actually to compete for their jobs, and they agreed with the enterprise after internal "tenders".

However, the monopoly positions, based on organisational relations, practice, special local knowledge and expertise, set a limit to competition "on the market" in the same way as the "cartels" of VGMKs did, in which action against knocking down prices was seen as a collective interest of all the inside contracting groups connected by everyday work and possessing common systems of norms and values. At the same time, the mechanism of submitting bids was devised by enterprise management "under the resource-allocating practice accustomed in a hierarchical organization".

"Each works manager wanted to submit for bids as many jobs as possible in his own area, because the additional resources of VGMKs facilitated the performance of his tasks and allowed him to offer extra income to his workers ... . In reality, biddings resulted from cooperation between managers and some VGMK representatives .... ." (op. cit.: 69).

As can be seen, a special situation in the market of VGMKs subjected to competition is brought about, not only by monopoly positions or cartel agreements, but also by coalitions of sellers (announcers of jobs) and 
buyers (VGMK contractors). In Neumann's statement, what can be formally disclosed are market features, bargains, accords, prices, but it is "precisely the regulatory, coordinative function of the market that cannot be observed" (op. cit.: 70). Demand and price reflect in the first place the balance of forces between partners, which is influenced by wage payment possibilities in full-time employment and the effect of the local labour market, just as by changes in the social and political environment. Consequently the use of market categories in enterprise wage bargaining has a special meaning, implying that through direct or indirect bargaining the participants come to agreement in accordance with the balance of forces. This concept can be correctly interpreted if "contrasted with the earlier concept of industrial relations", because it accepts bargaining as justified and "does not qualify as blackmail the behaviours of workers enforcing pay rises by reliance on bargaining positions" (op. cit.: 71).

Nevertheless, the nature of VGMK bargaining, differing from the market's in the original, economic sense of the term, does not mean that the functioning of the internal contracting groups is characterised by the forms of bureaucratic coordination shown by Kornai as an alternative to market regulation.

Even infraction or evasion from a considerable part of enterprise regulations (e.g. restrictions on earnings or manager's incompatibility) became subject of bargaining. From the absence of the market's regulatory functions and the practice of regular infractions of bureaucratic rules, we might deduce some sort of disorderliness of relations between enterprise and inside contracting groups. Prices, or member's incomes, are completely uncoordinated. VGMK incomes appear unregulated even to state economic management: payments to VGMKs open a channel for wage outflow evading actual wage regulations. Still, the case of VGMKs in competition shows that "manipulations" by managers and reactions of inside contracting groups form a more or less effective set of rules (op. cit: 72-73). Neumann thus comes to the conclusion that in the enterprise organization and the VGMKs' operation there is a mechanism which, "functioning horizontally", is "capable of regulating the allocation of jobs and earnable incomes".

He considers that this regulatory mechanism is more dominant than the limited effects of the market or the bureaucratic prescriptions and calls it "compensatory"; similar is such regulatory systems as Manchin/Szelènyi's institution of family self-help schemes which, enclaved between the roles of the State and the market in sharping housing conditions, "cushions" their effects (op. cit: 74, and Manchin/Szelènyi, 1988).

Neumann nevertheless mentions the term "deal" or "transaction" already used in the early 1970 s to characterize relations between or among interest groups within the enterprise (op. cit: 77, and Hèthy/Makó, 1972), 
terms which, based on and reproducing reciprocity, serve to integrate Tmicro-units of the enterprise.

The varied experience offered by the emergence and operation of VGMKs reinforces conclusions, drawn from other analyses, that segments of workers with high qualifications and organizational-social experience have a significant collective ability to affirm their interests at their work places, exerting their influence in a coalition of interests with the lower and middle levels of management. All this was signaled by previous analyses tracing the fate of some initiatives concerning work organization, technological development projects and incentive systems. The experience of VGMKs - given their spread and the large mass of people participating in them (nearly 200,000 employees in the mid-1980s!) - is of greater significance than was shown by earlier sociological case-studies, because inside contracting groups are of general relevance to understanding the nature of social change.

Their experience demonstrates that considerable masses of workers are able to legitimize, in the longer run, their demands for higher pay, professional skills and practice, local knowledge and cooperative relations within the framework of VGMKs, despite the rigid hierarchical and bureaucratic organizations and central wage regulations.

The same possibilities however though yielding different incomes, left different segments of workers, including unskilled and semi-skilled as well as organizationally and/or socially marginalized ones, with a new option, allowed them a scope of action, gave them a chance of earning extra income and last but not least, an opportunity of social learning.

The incomes of workers in large enterprises came closer to the income level in the second economy. There are two trends that can be observed to be at work simultaneously in this process: VGMK incomes increased income differentials on full-time jobs, while opening a perspective, for several groups or segments of enterprise workers at a disadvantage, to earn more (Neumann, 1987: 34). The VGMKs allowed higher-income groups to earn even more and certain marginal groups to earn extra income.

Thus, to eliminate shortfalls on performance which had been accumulating over the past decades, enterprise management not only entered into separate deals with some central segments of workers, but also had to mobilize the unutilized or underutilized performance capacities of marginal groups, so the continuously swelling of the ranks of well-paid enterprise workers and improvements in the situation of lower-income groups were mutually intertwining processes, one presupposing the other, even though they entailed increased differentiation.

After seven years of experience gained from these inside contracting groups, we should like to draw some important conclusions of relevance to 
understanding and shaping the learning ability and adaptability of Hungarian society.

First, cooperation is generated not only by hierarchical/bureaucratic or market mechanism, but also by social relations which open channels for action on the basis of mutuality/reciprocity. ${ }^{15}$

Second, all society has grown aware that the participants in the labour process are mutually dependent, with none of the partners possessing all the competence and resources required for success in bringing about change. This means that initiatives for change do not come from representatives of enterprise management and/or of central governing organs alone. Different groups of those directed have notable though unequal degrees of autonomy, that is perceivable only in the long term, in moulding and influencing social relations in the labour process.

Third, the existence and operation of VGMKs amounts to a most obvious criticism of the work of considerable groups in enterprise management. With their records of performance, these groups have questioned the raison d'être of certain functions and structures of management and have, even if transitorily, reinforced the social legitimacy of certain other managerial jobs which had been "downgraded" for decades.

Fourth, the experience of the internal contracting groups, with regard to the incentives, has impelled not only enterprise management, but also the government bodies concerned with wage and income regulation, to adopt innovative measures.

Finally, negotiations between representatives of these inside contracting groups and enterprise management about performance and wages brought into sharper focus the low efficiency of trade union representation of interests. The pragmatic duality in the practice of manpower utilization has

15 Even in extreme situations human cooperation is able to open room to survive and to act. This is perfectly illustrated in Solzhenitsin's classical short story. A "Day of Ivan Denisovich", from which we quote the following passage:

"“... the brigadier says to Pavlo in a low voice: 'You stay here, but crack on it! Meanwhile I am going to squeeze the percentage out of them.'

Much depends on percentages, much more than on the work itself. If a brigadier has brains, he goes the percentage tooth and nail. Food supply depends on it. Prove that you have done what you haven't; where the norm is high, try to knock it down, but to do so the brigadier must have a lot of finesse. And be in cahoot with the task-setter. His palm must be oiled, too.

All things considered, who needs those percentages after all? The camp does. This is the only way the camp can pocket from the construction works thousands of superflous roubles, to give bonuses to its own men. To the kind of Volkovoy with the whip. And you can get 200 grams more of bread for supper. And these 200 grams may well mean life!" (Solzhenitsin, 1989: 58-59). 
raised strong doubts about the goals of the working-class policy as officially represented by political organs official ideology.

Mistrust in the guidance of society, however, is not necessarily destructive or destabilizing, for social change is inconceivable without a certain measure of mistrust, manifestation of doubts being the first step towards increased control over the institutions governing society and a renewal of representative organs. Still, collective actions performed by VGMKs not only "challenged" the existing structures of management and direction, but also enriched the process of social learning, signaling possibilities of building trust after having proved a success in the participants' pursuit of their aspirations. ${ }^{16}$ With the emergence and spread of VGMKs, the models of interest coordination and agreements emerged from the world of hidden and informal bargaining and left room for broad masses to learn how to shape the pattern of social relations prevailing in the labour process.

16 It was not until recent years that the concept of trust in public opinion was given a social content in addition to the individual and psychological ones. In its individual aspect, trust instills into human beings a sense of permanence, order and firmbalance in their daily activities and moral world. So does it in every society: the sense of predictability, lasting security and continuity are, when there are frequent changes often unfavourable, indispensable for maintaining cooperation and social solidarity. It is the least visible tool of integrating society, but is also a factor of social control that makes its effect felt in the long run. It is usually said to have two components: one is technical competence, or professional skill, and the other is moral competence, i.e. assumption of responsibility for the community, toleration for one another's values and interests, and action in accordance with mutually observed norms. Beside increasing the technical competence of the self-regulating social subsystems, securing moral competence appears to be the more difficult task, though it is precisely trust based on moral competence that can forge cooperation and create stability in reducing mutual losses caused by sharp competition and tensions arising from the diversity of social and organizational relations (Makó, 1980). 


\section{Borning and Inherited Patterns of Cooperation as Indispensable Basis of Securing Social Stability and Renewal - General Conclusions}

From an analysis of the components and content of actions in the "trias" of labour, economy and society, there can be derived experiences of theoretical, methodological and practical nature.

First, an important lesson for the methods of our own research on labour and organizational sociology is this: suitable for disclosing the social aspects of the labour process is an analysis, not simply complex but multidimensional, of the internal relationships of the enterprise organization and the institutions that have to resolve conflicts in industrial relations. That analysis must consider, parallel to the social relations of the labour process as the immediate environment of action, the effects of other spheres of society, because individuals act, both in time and space, in several social formations, are actors and agents of several sets of social relations. We cannot interpret social processes, maintenance of stability, adaptation or conflict management, if we keep track of them in only one social formation and judge them by the criteria of a single rationality. Participants in the labour process pass from one formation to another and, in taking decisions, bind together the "social spaces" of their daily lives.

We have to learn to interpret human relations in terms of various sets of social relations carrying different contents rather than under an approach to a dominant form of production considered in terms of hierarchical and coordinative relations, forces and counter-forces.

Second, unsocial relations exolving in the labour process, there may accordingly coexist patterns of behaviour, values and cooperative structures which, in the spirit of the evolutionist concept of society, are said to belong to social and economic formations representing different stages of development to the so-called premodern forms of cooperation are present and at work even in the most modern structures, a afct which has questioned the validity of the paradigm that "modernization means abdition of the old society and the old models of community organization".

"The strength of an alternative is determined by convention and invention (or, in the words of Miklós Radnóti, tradition *and ingenuity). Its stabilization is proved by the fact of an emerging new equilibrium, when a tradition is coming within reach again. But recurrence presupposes a new approach" - wrote Sándor Radnóti in one of his studies (1988: 150).

We should form a new image of modernization and its conditions, reliance on traditions, governability, and the possibilities as well as limit of human action.

Third, cooperation within and among various spheres is regulated by 
several mechanisms in the reproduction of society, understood to be a discontinuous and heterogeneous formation. We consider the regulators present and acting in society as a corrective type of mechanism which is destined to maintain the reproduction of society in different spheres (family, production and services, settlement, etc.). Thus the motives and contents of social phenomena cannot be understood under the logic of one or two regulatory mechanisms. Thinking in terms of state (bureaucratic vs. market regulation, for instance, precludes understanding and mobilizing the mechanisms through which other social regulators exert their effects. The relationships governed by regulators cannot be arranged into a hierarchical pattern. They are amenable to separation only for purposes of scientific analysis, but are inseparably present in human activities. The effect of one or another social regulator is over-emphasized by different ordinary or political - ideologies enclaved between science and daily practice. Previously state intervention was considered to be the decisive integrative force of society, now it is rather market regulation, which is considered to be. Although in the light of international and Hungarian experience one comes more often upon expressions like "community market" (mercato communitario) or "market of life", which are joint products, an interplay, of the resource-allocative market in the economic sense and of the mutuality of human and social relations permeates both the interrelationship of enterprises/entrepreneurs and relations between partners cooperating in the enterprise organization.

The operation of a market conditioned by social relations calls into being bargainings like "relational contracting" in the economic practice of Japan (Dore, 1987); in those, account is taken not only of economic efficiency, but also of the existential security of community members, or partners in cooperation. Market relations thus permeated with relations of confidence may in this way operate systems like "just-in-time" production, a practice of enterprise management organizing production with a minimum of reserves and manpower. A market permeated with effects of social and political relations can similarly be shown to exist in the operation of inside contracting groups set up at Hungarian enterprises. Relations between contracting parties, engaged in such bargaining on the market, cannot be interpreted by means of either bureaucratic or market regulators. This implies not only that the introduction and application of market regulators come from immense collective efforts rather than from automatic change or from change ordered from above, but also that markets are of several kinds, with their structure and relationship to mechanisms regulating other social relations likely to vary considerably by the historical and political-cultural traditions of individual regions or countries. 
Fourth, since individual and social action cannot be interpreted safely in the "social space" constituing their immediate environment, and the reaction of various social groups may also appear in several speres, preocesses of social adepstation can be regarded as series of cummulative change brought about by various mechanism regulating human cooperation.

There may take place, without radical changes in the dominant regulation or one considered as such, significant technological and organizational innovations carrying the germs of potential social innovations. The contrary is equally true: spectacular changes in the institutions of society's direction are in themselves incapable to reconstruct mechanisms regulating the utilization or wasting of human resources. Central governing organs should be responsible to coordinate regulators operating in different spheres of society rather than to replace any one of them. (The use of complicated administrative techniques is a typical technocratic response to the guidance of complex societies in a state of flux, although simple responses are usually more effective, yet finding them requires much more experiences to be gained from human resources inherent in different subsystems of society). An ideal political, governing strategy can base itself on mechanisms already existing in, and regulating, human and social relations, but the ideological-conceptual obstacle to its doing so consists in our failure to "respect" society together with its characteristic patterns of functioning and with the specific features assuring its reproduction and survival.

The special processes of Hungarian society's adaptation to the market as well as to social and political changes similarly stem from longer historical processes and from social and cultural traditions.

The historical roots of the second economy, for instance, are analyzed by researchers in economic geography in connection with the spread of small-scale agricultural production and household farming in Hungary, with these conclusions drawn:

"The dual organization of Hungarian agriculture is not exceptional in WesternCentral Europe, but, just the contrary, derives from a century-old tradition. The capitalist development of agriculture took this special form from Prussia through Poland to Hungary and Rumania, that is to say that large estates were growing grains and industrial plants for external markets, while small subsistence peasant farms appeared on the market with labour-intensive products and livestock. This dual organization which had evolved under special and historical and economic conditions was disrupted twice over the past decades: first in 1945, when the land reform liquidated the system of large estates, which was a politically necessary step, but damaged agricultural production (its consequence being the introduction of the compulsory delivery system to secure supplies to the population), and later in the 1950 s, when collectivization did away with the system of the labour-intensive small-scale production as well. It was from the 1960s that, under a new set of social conditions, Hungarian agriculture recovered its dual organization, in which grains 
and industrial plants were grown by large farms, while labour-intensive plants, and animal products from honey to eggs came from small producers and household plots" (Csatàri/Egyedi, 1986: 103-104).

The centuries-old traditions of agrarian development, on the strength of which producers adapted themselves to objective conditions like the feudal character of land tenure, market demands, geographical and climatic conditions and the degree of technical development, served as a model in the course of change amid such conditions and signalled avenues of autonomous action by peasants vis-à-vis collectivization. Moreover, these avenues reproduced themselves for commuting workers living in rural areas.

Labour sociology studies of worker behaviours and organizational relationships during the 1960 s and the 1970 s pointed out to the presence of "dual strategy" in actions at the enterprise level and the differentiation of workers in terms of regular extra income from household farming or gardening (Hèthy/Makò, 1969; 1972; 1978). The duality of work at large agricultural and auxiliary/household farms as a centuries-old tradition has obviously exerted a strong influence on industrial workers as well. The effect of this socialization can be observed in tolerating and managing conflicts within the enterprise as much as in small undertaking of auxiliary activities in industry.

Fifth, individuals and groups of them naturally do not have uniform faculties and abilities for assimilating and exploiting the effects of different social regulatory mechanisms and maintaining and building sets of social relations subserving the former.

Consequently the emphasis is laid, not on inequality, but on diversity, because it is the analysis of such diversity that can provide a real basis for encouraging human and social adaptation. In like manner, the sociological concept of "equal opportunities" is far from a formal, narrow and mechanical notion of equality. Such heterogeneity is suggested by sociologists formulating the goal of creating various possibilities for rise from different social situations, possibilities that can be influenced by a variety of social means.

In given situations, for instance, only a part of the engineers of economic and technological change in enterprise organizations are able to become "actual partners" in influencing the results of change, namely those who in the various spheres of their work and activity have acquired professional-occupational and socio-political skills. In this "process of social learning" the enterprise organization itself functions as an "educational system". The character of technology, the structure of work organizations, the models of employment, the managerial methods, the mechanisms of one's progress, encouragement to and recognition of expertise, 
loyalty, competition and cooperation combine to orient and to educate the actors of enterprise organizations. Within particular organizations, certain segments become capable of and interested in dealing with and manipulating organizational relationships, while it may be more "remunerative" for other segments to exploit in other formations the skills and relationships they have built in certain productive spheres, where they however cannot profit by them.

Therefore, the model of manpower utilization used by society and enterprise management as the only profitable one in the longer run should give encouragement to the accumulation of professional, organizational and social knowledge.

Attention should be devoted primarily to non-privileged segments whose organizational positions as well as human and social relationships afford them little possibility to participate regularly in the processes of social learning. However, the failure of misrepresented efforts to affirm their interests in some organization or set of relationships does not automatically entail complete existential collapse for people belonging to several different communities or "networks" in or outside the direct environment of their work, but may even turn, in the long term, earlier risk into a useful experience in another social space, whereas people belonging to an isolated organization or community are apt to become loosers of change. Social processes, aiming at diversifying forms of production ${ }^{17}$ and it preserving diverse small communities - which support the heterogenization of property relations and political pluralization should be regarded as guarantees for society's adaptation, renewal and stability.

17 Deeper statistical analyses can give a more realistic idea of the Hungarian industrial organizations as well. Although the sphere of small and medium-sized industrial enterprises represents a lower ratio than in the advanced capitalist countries, "it is already of a decisively significant weight" (Romány, 1988: 20-21). Out of 1,007 state-owned industrial enterprises recorded in 1986, 440 units had a staff of less than 500 employees. The public sphere of industry consists of a total of 4,746 units, of which "as little as 490 had a staff of more than 500 employees, albeit the latter employed 61 percent of the total workforce" (op.cit.: 24). Also, the majority of the 1,107 industrial cooperatives consists of small and medium-sized units, with only 48 having a staff of more than 500 physical workers. Among the smaller industrial production units we can count with those too which provide employment for some 200,000 people in other than industrial sectors of the economy, for two-thirds of that number in agricultural organizations. "A great majority of them enjoy almost complete autonomy in daily operations and are in a dependent position only in matters of development" (Romány, 1988: 24). 
There is ample experience to show that in grave crisis situations of particular organizations and regions, the professional and organizational knowledge acquired and the sets of human and social relations built in the course of social learning can be mobilized not only for a concrete arrangement, but as a social capital used for stabilizing and renewing society, also for opening new alternatives for human action in other than conflict situations, evading and relaxing (perhaps eliminating) the frameworks of conflict. It is in this sense that periods of crisis, protests and mistrust make it clear that there are, present in society, resources that not only sustain conflicts, but are also capable of removing them. Behind the "resistance" ore passivity of society's actors, manifest in a given situation or social space, one finds their "collective" knowledge acquired in other spheres or formations. Such collective knowledge is a human and cultural capital hard to gain and easy to loose, one that is capable of renewing society more profoundly than many of the large investment projects and institutional reforms.

\section{References}

Amiot, M.: Contre l'État, les sociologues. Paris, Editions de l'École des Hautes Études en Sciences Sociales, 1986.

D'Andrea, R.: Formation et nouveau statut professionnel. Milano, Istituto Intervento sui Sistemi Organizativi, 1982.

Angelusz, R. \& R. Tardos: 'Válogatás kapcsolathálázati elemzés irodalmából (Selections from studies on Network Analysis)', Szociologiai Figyelo, No. 3 (1988).

Ascoli, U. \& R. Catanzaro (Eds.): La società italiana degli anni ottanta. Roma-Bari, Laterza, 1987.

Barber, B.: The Logic and Limits of Trust. New Brunswick, Rutgers University Press, 1983.

Bagnasco, A.: 'La costruzione sociale del mercato: strategie di impresa e esperimenti di scala in Italia', Stato e Mercato, No. 13, Aprile (1985).

Becattini, G.: 'Riflessioni sullo svilluppo socio-economico della Toscana in questo dopo-guerra', in Storia d'Italia, Torino, Einaudi 1985.

Berki, S. \& Cs. Makó (Eds.): A szervezetfejlesztés alternativái és a vezetés (Alternatives to the Development of Organizations and Management), Budapest, Országos Vezetöképzö Központ, 1988.

Berki, S.: Gondolatok a VGMK társadalmi szerepéröl (Reflections about the Social Role of the VGMK). Budapest, MTA Szociológiai Kutató Intézet (Kézirat/Manuscript), 1984. 
Bernier, C. \& C. Cailloux: Les qualifications: un enjeu des nouvelles technologies? Montréal, Institut de Recherche Appliqué sur le Travail, 1985.

Bernier, C.: Nouvelles technologies, qualifications et formation (Resumé de projet de recherche), Montréal, Institut de Recherche Appliqué sur le Travail, 1986.

Bogdan, J.: A szervezéssel foglalkozó párt- és kormányhatározatok áttekintése a munkaszervezetekkel foglalkozó kutatások szempontjából (A Review, from the Viewpoint of Research on Work Organizations, of Party and Government Decisions Concerned with Organization.). Budapest, ABMH Munkaugyi Kutatointezet, 1981.

Bossanyi, K. \& L. Nyikos: Együitt dönteni: párbeszéd és meditáció a kollektív vezetésröl (Deciding in Common: Dialogue and Meditation about Collective Management). Budapest, Közgazdasági és Jogi Könyvkiadó, 1987.

Boyer, R.: 'Les transformations du rapport salarial dans la crise - une interpretation des aspects sociaux et économique', Critique de l'Économie Politique, No. 15, 1981.

Braczyk, H. J.: Work in Foundries, Sofia: Paper Presented for Workshop ISA-RC 30, Sociology of Work, 1984.

Bruno, S.: Micro-Flexibility and Macro-Rigidity. Expectations and the Dynamics of Aggregate Supply. Roma, Istituto di Economia, October, 1986 (Manuscript).

Bruno, S: Évaluation des mesures nationales en faveur de l'emploi des jeunes. Paris, La Commission des Communautés Européennes, Octobre, 1987.

Bryn, J. \& S. Wood: 'Qualification tacite, division du travail et nouvelles technologies', Sociologie du Travail, No. 4, 1984.

Buitelaar, W. L. (Ed.): Technology and Work. Labour Studies in England, Germany and the Netherlands. London, Gower Publishing Company Ltd., 1988.

Burawoy, M \& J. Lukacs: 'Mítoszok a munkáról: gyárak összehasonlítása egy szocialista és egy fejlett tökés országban (Myths about Work: A Comparison of Factories in a Socialist and an Advanced Capitalist Country'), Tàrsadalomkutatás, No. 2, 1987.

Butera, F.: Quelques considérations à propos de la recherche de 1'Est: Production de la hiérarchie dans l'entreprise. Milano. Istituto di Ricerca Intervento sui Sistemi Organizativi, 1978.

Butera, F.: Lavoro umano e prodotto tecnico. Torino, Einaudi, 1979.

Butera, F.: L'orologio e l'organismo. Milano, F. Angeli, 1984.

Csillag, I.: 'Korlátolt felelössegü becslés. Gazdasági Társaságok (A Limited Liability Estimate/Business Partnerships)', Heti Világgazdaság, Vol. 8, 1989, No. 509: 11.25-52-55. 
Coriat, B.: 'Transfert des techniques, division du travail et politiques de main d'oeuvre: une étude de cas dans l'industrie Brésilienne', Critique de l'Économie Politique, No. 14, 1981.

Crozier, M.: A bürokrácia jelensége (The Phenomenon of Bureaucracy). Budapest, Közgazdasági és Jogi Kiadó, 1981.

Crozier, M.: L'État modeste, l'État moderne. Stratégie pour un autre changement. Paris, Éditions Fayard, 1987.

Csatari, B. \& Gy. Enyedi: in Gy. Enyedi \& J. Weldman (eds.), 1986.

Dallago, B. (1988): Szabálytalan gazdaság Olaszovoszágban, Közgazdasági Szemle, 7.-8.

Dohse, K.; Jürgen, U. \& T. Malsch: 'From "Fordism" to "Toyotism"? The Social Organization of the Labour Process in the Japanese Automobile Industries', Politics and Society, 1987.

Dore, R.: Taking Japan Seriously. A Confucian Perspective on Leading Economic Issues. Stanford, Stanford University Press, 1987.

Dozsa, L.: 'A vàllalaton belüli irányitási rendszer néhány idöszerü kérdése (Actual Questions of the Management System within the Enterprise)', Társadalmi Szemle, No. 7, 1971.

Dubois, P.: 'A munka és az új technológiák (Work and New Technologies)', Ergonómia 1, 1988: 13-31.

Dubois, P.: \& M. Giannini: 'Le travail ouvrier en groupe dans les entreprises industrielles de l'ouest et de l'est', Revue Française des Affaires Sociales, Août, 1985.

Dubois, P. \& Cs. Mako: Penurie de main d'oeuvre et flexibilité de l'emploi en Europe de l'Est. Paris, La Documentation Française, 1988.

Edstrom, A.: Scandinavian Airlines System (SAS). An example of Business and Social Reform. Stockholm, FA-radet, 1988.

Ekstedt, E. \& R. Henning: Globalization and Local Mobilization. Stockholm, The Swedish Council for Management and Work Life Issues, 1988.

Enyedi, Gy. \& J. Weldman (Eds.): Rural Development Issues in Industrialized Countries. Budapest, Centre for Regional Studies of the Hungarian Academy of Sciences, 1986.

Etzioni, A.: A Comparative Analysis of Complex Organizations. On Power, Involvement and Their Correlates. New York, The Free Press, 1975 .

Farkas, Z:: 'Munkások érdek- és érdekeltségi viszonyai (Worker's Interests and Interest Relations)', Szociológia, No. 1-2, 1983.

Fazekas, K: 'Bér- és teljesítmenytárgyalások a belsö munkaeröpiacokon (Wage and Performance Bargaining in the Internal Labour Markets)', Budapest, MTA Kozgazdasagtudomanyi Intezet Tanulmanyai, Vol. 23, 1984: 27-52.

Freyssenet, M.: La division du travail. Paris, Édition Savelli, 1977. 
Friedman, A.: Industry and Labour: Class Struggle at Work and Monopoly Capitalism. London, Macmillan, 1977.

Fua, G. \& C. Zacchia: Industrializzazione senza frattura. Bologna, Il Mulino, 1983.

Gabor, R.I.: 'Második gazdaság: a magyar tapasztalatok (The Second Economy: Hungarian Experiences)', Valóság, No. 2, 1985.

Gorbachev, M.: Az átalakítás és az uj gondolkodás (Perestroika and the New Thinking). Budapest, Kossuth Könyvkiadó, Pallas Lap- és Könyvkiadó, 1987.

Gramsci, A.: Selection from Prison Notebooks. London, Lawrence and Wishart, 1971.

Granovetter, 'Economic Action and Social Structure: The Problem of Embeddedness', American Journal of Sociology 91/1985 (3): 481-510.

Grinzberg, E. \& G. Vojta: Beyond Human Scale. The Large Corporation at Risk. New York, Basic Books Inc. Publishers, 1985.

Gross, E. \& A. Etzioni: Organizations in Society. Englewood Cliff, Prentice Hall Inc., 1985.

Grootings, P.; Gustavsen, B. \& L. Héthy (Eds.): New Forms of Work Organization in Europe. New Brunswick-Oxford, Transaction Publishers, 1986.

Gyenes, A. Jr.\& T. Rozgonyi: Az alá ées fölélerendeltségi viszonyok a szervezetekben (Hierarchical Relations in Organizations), Budapest, Akadémiai Kiadó, 1981.

Gyenes, A. Jr.\& T. Rozgonyi: Management - Subordinate Relations in Industrial Organizations. Budapest, Institute of Sociology, Hungarian Academy of Sciences, 1989.

Henning, R.: Regional Policy: Implementation through Bargaining. Stockholm, The Swedish Council for Management and Work Life Issues, 1983.

Henning, R.: Sweden: Political Interference with business, in The Politisation of Business in Western Europe. London, Croom Helm, 1986: 18-38.

Héthy, L.: Vállalatirányítás és demokrácia (Entreprise Management and Democracy). Budapest, Közgazdasági és Jogi Könyvkiadó, 1983.

Héthy, L. \& Cs. Mako: 'Munkateljesítmény, érdek, hatalom, környezet. $\mathrm{Az}$ egyengetö lakatosok esete (Work Performance, Interest, Power and Environment/The Case of Strainthening Fitters)', Uj Irás, Vol. 11, No. $2,1971$.

Héthy, L. \& Cs. Mako: Munkásmagatartások és a gazdasági szervezet (Workers' Behaviour and the Economic Organization). Budapest: Akadémiai Kiadó, 1972.

Héthy, L. \& Cs. Mako: Munkások, érdekek, érdekegyeztetés (Workers, Interests, Bargaining). Budapest, Gondolat Kiadó, 1978. 
Holtback, R.: 'Sweden: Balancing Human Possibilities and Technology', US Department of Labor, Labor Relations Today, May-June 1988.

Horvath, L.: 'Participáció, üzemi demokrácia (Participation, Shopfloor Democracy', Közgazdasági Szemle, No. 4, 1975.

Hoof, J. Van \& R. J. Huiskamp: New Forms of Work Organization: The Dutch Experience (Lecture on "New Forms of Work Organizations and Their Socio-Economic Environment"). International Conference, Siófok, May 1984.

Juhasz, P.: 'A településfejlesztési koncepció és a faluosztályok elmélete (The Concept of Settlement Development and the Theory of Village Classes)', Tér és Társadalom, No. 2, 1988.

Jürgen, U. \& H.P. Strömel: The Communication Structure between Management and Shop Floor - A Comparison of a Japanese and German Plant. Berlin, WZB Discussion Paper 11 VG 86-204, 1986.

Kalleberg, R: Workplace Democracy and Economic Democracy. Centre of Socialist Studies of Israeli Labour and Kibbutz Movement, Haifa, 7-12 January, 1988.

Kasvio, A.: A New Stage in the Development of Industrial Work, Tampere, University of Tampere, 1985.

Kasvio, A.: Industrial Restructuring in the 1980s and the Theoretical Reconstruction of Industrial Sociology. Jablona, ISA-RC Sociology of Work, 1986.

Kern, H. \& M. Schumann: 'Vers une professionalisation du travail industriel', Sociologie du Travail, No. 4, 1985.

Kertesi, G. \& Gy. Sziracki: 'Munkásmagatartások a munkaeröpiacon (Workers' Attitudes in the Labour Market)', Valóság, No. 3, 1983.

Koestler, A.: The Gost in the Machine. London, Picador, 1976.

Kövari, Gy.: 'Munkaerö - teljesítmány osztönzés (Workforce - Performance - Incentives)'. Közgazdasági Szemle, No. 4, 1984.

Kornai, J.: A hiâny (Shortage). Budapest, Közgazdasági és Jogi Könyvkiadó, 1980.

Kornai, J.: 'Bürokratikus és piaci koordináció (Bureaucratic and Market Coordination)', Közgazdasági Szemle, No 9, 1983.

Kovacs, K.: 'A lokális autonomia összetevöiröl Baranya megyei példák alapján (On the Components of Local Autonomy on the Basis of Examples from Baranya County)', Tér és Társadalom, No. 2, 1988.

Köllö, J.: 'Taktikázás és alkudozás az ipari üzemekben (Manoeuvring and Bargaining in Industrial Plants)', Közgazdasági Szemle, No. 7-8, 1981.

Kuczi, T.: 'Cselekvési térképek - gazdasági gondolkodásmódok (Maps for Acting - Economic Thinking)', Valóság, No. 7, 1987.

Lado, M. \& F. Toth: Egy ipari üzem munkaszervezete. A hianyjelzesre epulö munkaszervezet (The Work Organization of an Industrial Plant/A 
Work Organization Responding to Signals of Shortage). Budapest, ABMH Munkaügyi Kutató Intézete, 1982 (Kézirat/Manuscript).

Lado, M. \& F. Toth: 'A hivatalos szabályozás árnyékabán (In the Shadow of Official Regulation)', Mozgó világ, 1985, Vol. 1.

Lado, M./Simonyi, A. \& F. Toth: 'From Taylorism to New Forms of Work Organization in Hungary', in Grootings, Gustavsen \& Héthy (Eds.), New Forms of Work Organization in Europe, New Brunswick: Transaction Publishers, 1986.

Laki, M.: 'A kényszeritett innováció. Muszaki fejlesztes az eladok piacan (Enforced Innovation/Technical Development in Sellers' Market)', Szociológia, 1984-85: 46-52.

Laki, T. \& L. Neumann: Vállalati vélémenyek a VGMK helyzetéröl (Enterprise Opinions about the VGMK's situation). Budapest, ABMH Munkaügyi Kutatóintézete, 1988.

Lengyel, Gy.: 'Fiatal közgazdászok a gazdasági szervezetben (Young Economists in the Economic Organization)'. Budapest, MSZMP KB Társadalomtudományi Intézet, February, 1984.

Lutz, B:: Social Endogeny of Technical Progress and the Question of Development of Human Labour. Commission of the European Communities - First Community Symposium in Social Science. Pont-àMousson, 3-4 September, 1981.

Makó, Cs.: A társadalmi viszonyok erötere: a munkafolyamat (The Labour Process, as an Arena of Social Fighting). Budapest, Közgazdasági és Jogi Könyvkiadó, 1985a.

Makó, Cs.: 'Szervezeti innováció és a munkafolyamat (Organizational Innovation and the Labour Process)', Valóság, No. 2, 1985/b.

Makó, Cs.: Critique des categories et des concepts retenues dans l'analyse comparative. Table Ronde: La Comparaison Internationale dans l'Étude du Travail Industriel, Paris, 1-3 June, 1988.

Makó, Cs.: 'Mi a bizalom? (About Trust...)', Élet és Tudomâny, No. 45 , 4 November, 1988.

Mánchin, R. \& I. Szelényi: Szociálpolitika az államszoci-alizmusban, (Social Policy and State Socialism). Budapest, Minerva Kiadó, 1988.

Maurice, M.: New Technologies and the New Model of the Firm: Change and Social Reproduction. Aix-en-Provence, Laboratoire d'Économie et de Sociologie du Travail, 1988.

Maurice, M.; D'Iribarne, A.; Eyraud, F. \& F. Rychener: Des entreprises en mutation dans la crise: Apprentissage des technologies flexibles et emergence de nouveaux acteurs. Aix-en-Provence, Laboratoire d'Économie et de Sociologie du Travail (LEST), 1986.

Maurice, M.; Sellier, F. \& J.J. Silvestre: The Social Foundation of Industrial Power. Boston, M.I.T. Press, 1986. 
Moravec, H.: Mind Children. The Future of Robot and Human Intelligence. Cambridge/Mass., Harvard University, 1988.

Nagy, K.: New Technology and New Forms of Work Organizations Comparative Study. Budapest, Institute of Labour (Mimeo), 1987.

Nagy, Kjsimonyi, A. (1983): Aszervezés határai, az ösztönzés Korlátai, Budapest: ABMH Munkaijgyi Katató Julézete.

Naville, P.; Bardou, J.P.; Brahet, Ph. \& C. Lévy : L'État Entrepreneur: le cas de la Régie Renault. Paris, Éditions Anthropos, 1971.

Némedi, D.: Talcott Parsons a társadalmi rendszerekröl. Válogatás (Talcott Parsons about Social Systems. Selections). Budapest, ELTE Szociológiai Intézet Továbbképzö Központ, 1988.

Neumann, L.: 'A VGMK és az intézményes érdekegyeztetés (The VGMK and Institutional Coordination of Interests)', Közgazdasági Szemle, No. 10, 1987a.

Neumann, L.: Tevékenységek, létszámösszetétel, jövedelmi aranyók. Statisztikai adatok a vállalati gazdasági munkaközösségekröl (Activities, Workforce Structure, Income Distribution. Statistical Data on Internal Subcontracting Groups). Budapest, ABMH Munkaügyi Kutatóintézet (Kézirat/Manuscript), 1987b.

Neumann, L.: 'Piaci viszonyok az üzemi béralkuban? (Market Relations in Wage Bargaining at the Enterprise?)', Gazdaság, No. 4, 1988.

Okubayaski, K. (1986): Work Content and Organizational Structure of Japanese Enterprise under Microelectronic Innovation, Kobe: Kobe University Business Scool.

Peter, T.: 'New Products, New Markets, New Competition, New Thinking', The Economist, 4-10 March, 1989: 27-30.

Piore, M.J. \& Ch.F. Sabel: The Second Industrial Divide. Possibilities for Prosperity. New York, Basic Books, 1984.

Polanyi, K.: Az archaikus társadalom és a gazdasági szemlélet (Archaic Society and Economic Thinking). Budapest, Gondolat Kiadó, 1976.

Radnoti, S.: 'Mi az, hogy beszélgetés? (What Does Conversation Mean?'). Budapest, JAK Füzetek, 36, Magvetö, 1988.

Reynaud, J.D.: 'Conflits du travail, classes sociales et contrôle social', Sociologie du Travail, No. 1, 1980.

Reyneri, E.: Innovazione produttiva - societta heterogenea. Paper at the Conference of Italian Industrial Sociologists, Milan, November, 1987.

Romany, Z.: 'A szocialista vállalat és a VGMK. A vállalati gazdasági munkaközösségek kezdeti tapasztalatai (The Socialist Enterprise and the VGMK/Initial experience of the Internal Subcontracting Groups)', Társadalmi Szemle, No. 6, 1983.

Romany, Z.: 'A kis ées középvállalatok helyzete és jövöje az iparban (The Situation and Future of Small and Medium-Size Enterprises in Industry)', Ipargazdasági Szemle, No. 3, 1988. 
Sabel, Ch. F.: Work and Politics. The Division of Labour in Industry. Cambridge University Press, 1982.

Sabel, Ch. F.: The Reemergence of Regional Economies. Paper prepared for the SSRC Western European Committee (Experimenting with Scale), August, 1987.

Sainsaulieu, R.: Sociologie de l'Organisation et de l'Entreprise. Paris, Presses de la Fondation Nationale des Sciences Politiques - Dalloz, 1987.

Simonyi, A. (Ed.): A teljesítménynövelés feltételei a munkaszervazetben (Conditions for Increasing Performance in the Work Organization). Budapest, ABMH Munkaügyi Kutató Intézet, 1983.

Simonyi, A.: Trsadalmi, politikai viszonyok az olasz kisvállalkozások fellendülése mögött (Socio-Political conditions behind the Revival of Small Enterprises in Italy). Budapest, MTA Szociologiai Kutató Intézet (Kézirat/Manuscript), 1987a

Simonyi, A.: Az olasz nagyvállalatok alkalmazkodásának társadalmi szabályozó mechanizmusa (The Social Regulation of Large Enterprise Adaptation in Italy). Budapest, MTA Szociológiai Kutató Intézet. (Kézirat/Manuscript), 1987b.

Simonyi, A.: Nagyvállalatok alkalmazkodása, rugalmas kisvállalkozások Olaszországban (Adaptation of Large Firms, Flexible Small Enterprises in Italy). Budapest, Kandidátusi Disszertáció (Ph.D. thesis), $1987 \mathrm{c}$.

Spitzchen, B. (1985): Computer Scientist Thinks Society Isn't Figured Into Eguation, Los Angeles Times, January 16. Part V.

Stark, D.: Markets inside the Socialist Firms: Internal Subcontracting in the Socialist Enterprise. Washington, Annual Meeting of the American Sociological Association, 1985.

Stark, D.: 'Rethinking Internal Labor Markets: New Insights from Comparative Perspective', American Sociological Review, August 1986.

Stark, D.: 'Osztályozás és szelektiv béralku a belsö munakeröpiacon (Classification and Selective Wage Bargaining in the Internal Labour Market). Gazdaság, No. 4, 1988.

Stark, D. \& V. NEE: 'Toward' an International Analysis of the State Socialism', in Stark-Nee (eds.): Remaking the Economic Institutions of Socialism. Stanford, Stanford University Press, 1988: 1-31.

Szabo, K.: 'Kifordítom, befordítom, mégis piac ... (Turned inside out, outside in it is still a market ...)', Közgazdasági Szemle, No. 11, 1986.

Solzhenitsin, A.: 'Ivan Gyenyiszovics egy napja (A Day of Ivan Denisovits)'. Budapest, Európa Könyvkiadó, Társadalmi Szemle (1989): Special issue, 1989. 
Tellér, Gy.: 'Omechanizmus, ujmechanizmus, ipari szövetkezetek (Old Mechanism, New Mechanism, Industrial Cooperatives)', Medvetánc, No. 4-5, 1984-85.

Tellér, Gy.: Adalékok a szövetkezetek gazdasági és jogi reformjăhoz (Glosses on the Economic and Legal Reform of Cooperatives)?. Budapest, MTA Allam- és Jogtudományi Kutatások Programirodája, 1987.

Trigilia, C.: 'La regolazione localistica: economia e politica nelle area di piccola impresa', Stato e Mercato, No. 2, 1985.

Voszka, É.: Reform és átszervezés a nyokcvabas években (Reform and Reorganization in the 1980s). Budapest, Közgazdasági és Jogi Könyvkiadó, 1988.

Walton, R.: 'From Control to Commitment in the Workplace', Harvard Business Review, March-April, 1985.

Wood, S.: The Degradation of Work? Skill, Deskilling and the Labour Process. London, Hutchinson Publishing Group, 1982.

Wood, S.: Toward Socialist-Capitalist Comparative Analysis of the Organizational Problem. London, London School of Economics, Department of Industrial Relations, 1985.

Wood, S.: 'From Braverman to Cyberman: A Critique of the Flexible Specialization Thesis', in W. Buitelaar (Ed.), Technology and Work: Labour Studies in England, Germany and the Netherlands. Aldershot/Hampshire: Gower Publishing Group, 1988: 28-42. 